
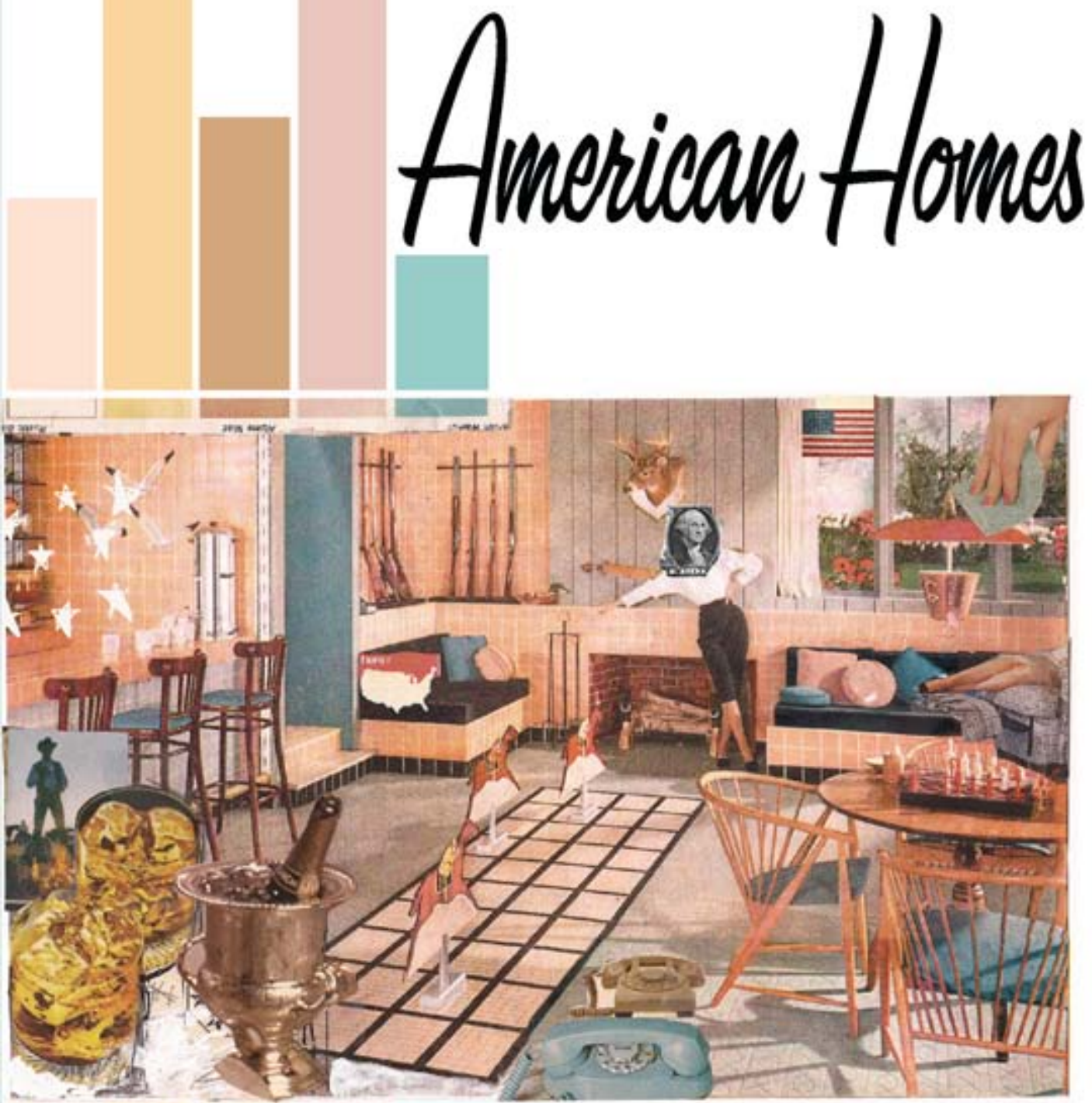

Ryan Ridge 


\section{Advance Praise}

Ryan Ridge has toppled everything. An insane and brilliant book that travels the American Home while moving ever further into the mind. What is possible in writing feels different now.

-Amina Cain, author of Creature

Ryan Ridge's American Homes is a guidebook gagbook rulebook dreambook thoughtbook freakbook stylebook cookbook mapbook. It's overflowing with ideas, with mental diagrams and musings on the vast contraptions that surround us every day. Somewhere between Perec and Brautigan, between Barthelme and Markson, Ridge emerges from the rhizome of rooms we call today and nudges it in the ribs until there's a hole there for you to stick your head in and inhale the funny bubbles of fresh blood. -Blake Butler, author of 300,000,000

In the kitchens in Ryan Ridge's American Homes are Cuisinarts into which he pours the words he bakes into loaves of prose, more wry than rye. The sandwiches he makes from them are fun to eat but leave a bitter taste in the mouth because the Land of American Homes is, after all, a bitter place. Still: the American Home is "shooting sunbeams out of its eye sockets" so welcome home. And welcome Ryan Ridge's American Homes into yours! -Denis Wood, author of Everything Sings

Ryan Ridge inflects his anatomy of suburban interiors with a madcap, panoptic conceptualist idiom, and his readers will be left feeling they never gave nearly enough thought to the stuff that real, 
lived life comprises: walls, floors, doors, windows, garages, sheds, attics and basements. Ostensibly a tongue-in-cheek meditation satirizing the homogenization of contemporary domestic space, American Homes develops a truly heterogeneous literary architecture founded on the basis of formal dynamism and linguistic play. -Evan Lavender-Smith, author of From Old Notebooks 
AMERICAN HOMES 



\title{
AMERICAN HOMES
}

\author{
Ryan Ridge
}

University of Michigan Press

Ann Arbor 


\section{Copyright (C) 2015 by Ryan Ridge All rights reserved}

This book may not be reproduced, in whole or in part, including illustrations, in any form (beyond that copying permitted by Sections 107 and 108 of the U.S. Copyright Law and except by reviewers for the public press), without written permission from the publisher.

Published in the United States of America by the University of Michigan Press

Manufactured in the United States of America

$$
2018 \quad 2017 \quad 2016 \quad 2015 \quad 4 \quad 3 \quad 2 \quad \text { I }
$$

DOI: http://dx.doi.org/I0.3998/tfcp.I3240727.000I.00I

ISBN 978-0-472-07258-3 (hardcover : alk. paper)

ISBN 978-0-472-05258-5 (paper : alk. paper) ISBN 978-0-472-I2099-4 (e-book) 
for Michelle L. 
The strength of a nation derives from the integrity of the home.

-CONFUCIUS

Everybody needs a home

Takes centuries to build

And seconds to fall

-STEPHEN MALKMUS 


\title{
Contents
}

\author{
Acknowledgments $x i$ \\ Part III (anatomy) I \\ Different Voices / Different Rooms 64 \\ Ideas $9 I$ \\ Index III \\ Home Builders' Association II5 \\ Books in the Series II6
}





\section{Acknowledgments}

Acknowledgment is made to the following publications in which sections of this book first appeared, sometimes in slightly different forms and sometimes under slightly different titles: Artifice, Bull, The Collagist, DIAGRAM, elimae, Everyday Genius, Kitty Snacks, Lamination Colony, Nailed, The Mississippi Review, Pear Noir, Salt Hill, Specter, Stoked.

This book would not exist without help, support, and inspiration from the following people: Blake Butler, Amina Cain, Ron Carlson, Gabe Durham, Ashley Farmer, Luke Goebel, Alan Grostephan, Jacob Heustis, Evan Lavender-Smith, Ben Marcus, Aaron McCollough, J.A. Tyler, Matthew Vollmer, and Denis Wood.

Thank you.

All illustrations are by Jacob Heustis. 

Part III

(anatomy) 
2 Ryan Ridge

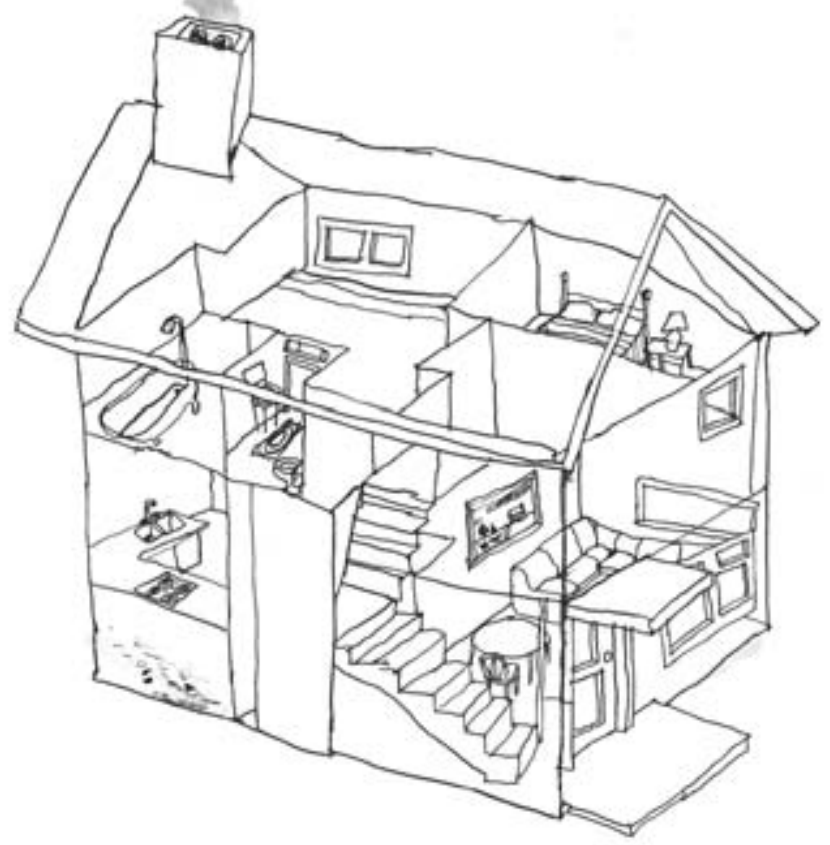


American Homes is a book. American Homes is an idea. American Homes is a book of ideas. American Homes is just beginning. American Homes is about to end. American Homes is the foundation of all unions. American Homes is the soundtrack to our American lives. American Homes is the disinclination of individual states to yield power to the federal government. American Homes is powerlessness. American Homes is slow evolution. American Homes is not just black and white. American Homes is great for families. American Homes is better for business. American Homes is targeted at affluent women with a flair for the unconventional. American Homes is aimed at men who are comfortable with their feelings about their feelings. American Homes is feeling much better. American Homes is never worse. American Homes is an obstacle course. American Homes is between shopping centers and the skeletons of factories. American Homes is distinctly American. American Homes is illegal in Iran. American Homes is taking narcotics. American Homes is living in Tucson. American Homes is dying in Florida. American Homes is internationally known. American Homes is home movies about home movies. American Homes is a technical fact. American Homes is saving coupons and the world. American Homes is very lucky to have you. American Homes is difficult to forget. 


\title{
PORCH PLATITUDES
}

\author{
FRONT PORCH-PORCH SWING-BACK \\ PORCH-CLARENCE
}

\section{FRONT PORCH}

The Front Porch is the prologue to an American Home. Or perhaps an American Home is the prologue to the Front Porch. It depends on whose home. Also: it matters who is home. Depending on these variables the Front Porch (also called the "Initial Perch") is a place where a wide variety of people post-up. For instance, at a Cocktail Party (See: Domestic Festivities) the smokers are generally sequestered to this area where they swap avantgarde tales of the afternoon in between coughing jags. According to the $\mathrm{Nu}$ American Center for Statistical Analysis (NACSA), a person appears $40 \%$ more attractive with a cigarette in his or her hand. Hence the Front Porch (AKA "The Smoker's Outlet") is I20\% more attractive when three or more people are smoking on it. It is the customary place where "Guests" wait for the Homeowners to acknowledge their presence. It is also the altar where teenage boys kneel and pray that their date's father does not answer the Door (See: Front Door). Front Porches are generally decorated with benches, rocking chairs, hammocks, and Porch Swings. Other key components of the Front Porch: animal carcasses and welcome mats. If a Porch has a welcome mat, consider yourself welcomed and invite yourself in. However, if a Porch is adorned with an animal carcass, say a goat skull smeared with vir- 
gin blood, go somewhere else. Quickly. Many U.S. Porches are super-patriotic and feature prominent American flags flapping in the American breeze like proud testaments to $18^{\text {th }}$ century optimism. The Front Porch is one of the great nostalgias of our time. Which time? This time, which means: No time to look back. Even less time to crawl inside our minds. Here we are. Where? I don't know. Look. Look at the Porch Swing.

\section{PORCH SWING}

The Porch Swing is a Post-Cynical literary device. It propels the plot forward, then back, then forward again. Often errors and felonies create excellent narratives. However, the Porch Swing is not now, nor has it ever been, either of those things. The Porch Swing is innocent. It is also a symbol of freedom in the book American Homes. 
6 Ryan Ridge

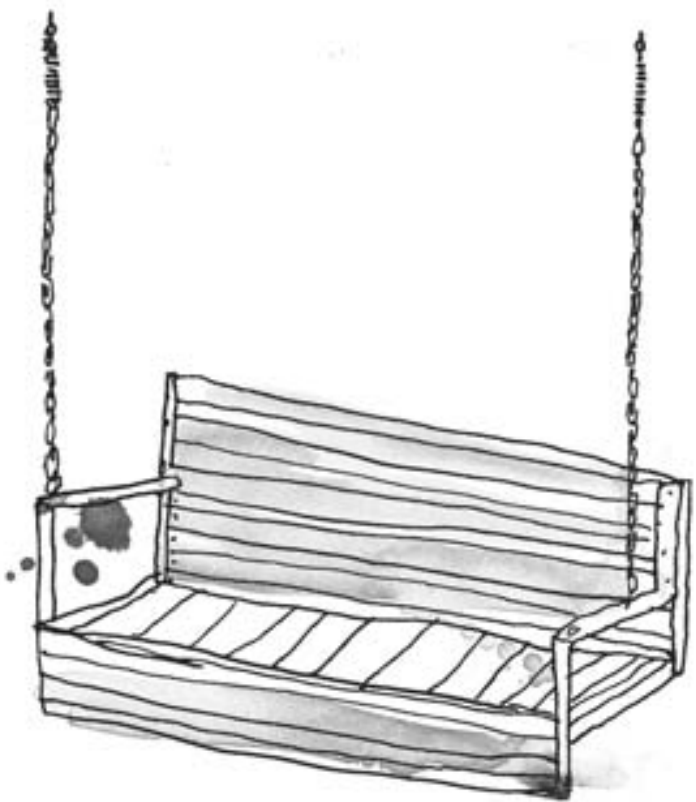

Figure I Porch Swing: I figure in the 2Ist century that the Porch Swing will replace the Desk Chair as the preferred furniture for literary composition. 


\section{BACK PORCH}

Historically, the Back Porch (also called the "The Place Where the Bastard Sits") is the place where ornery operators of human machinery once sipped sharp lemonade in the antebellum shade while musing about insignificant shit as their slaves and serfs toiled in the murky, bloody fields. Fortunately, after the awesome and inevitable triumph of the civil rights movement, Back Porches were forever shamed and screened and covered and all but replaced by Decks and Patios (See: Decks $\mathcal{E}$ Patios. NOTE: You won't find them in this book, but you will find them in many American homes). Thank God, too, because the Back Porch has always been, and always will be, backwards.

\section{CLARENCE}

So I was swinging on a porch swing the other night, writing American Homes in my beat-up yellow legal pad, trying to think of a title for the Porch section, when a gentleman approached me with a sawed-off shotgun and asked me what the hell I was doing. I told him I was writing a book about American Homes, and he told me maybe I should write my book about American Homes elsewhere. He said, "This is my American home, friend." I said, "And it's a beautiful American home, sir, which is precisely why I've chosen to write a section of my book here on your front porch." He said, "Why don't you write your book on your own front porch?" I said, "Because I live on the second floor of an apartment complex. I don't have a porch.” He put down his shotgun, grunted, and sat next to me on the swing, "Got a name?" "Ridge," I said. 
"Clarence," he said. We shook hands. "So you're a writer there, Ridge?" I considered it, said: "More like a cataloguer I guess." "Do you like Clancy?" he said. "No," I said. "What's your book about?" he said. "American Homes," I said. "What about American homes?" he said. "Everything about American homes," I said. "Right now, I'm writing about Porches." "Let me see what you've got," he said. So I did. I handed Clarence the legal pad and he examined my Porch notes. "Hell," he said. "This is nothing but a bunch of goddamn platitudes." "Thank you, Clarence," I said. "I think I've just found my title." "What's your title?" he said. "Porch Platitudes," I said. "That's a terrible title," he said, and we sat there for a very long time and I forget what we talked about. "Hey," I said, eventually, noticing something strange in the corner of the porch. "What's in the corner over there?" "That," Clarence said, pointing, "is a raccoon." "Yes," I said, "but what's that thing the raccoon is licking?" "Oh that," Clarence said. "That is a goat skull smothered in virgin's blood." There was a beat or two of silence. I said, "I better go." "Yes," he said. "You'd probably better." 


\section{DOOROGRAPHICAL DIVISIONS}

FRONT DOOR-BACK DOOR-SIDE DOOR-GARAGE DOOR-PATIO DOORS-FRENCH DOOR-STORM DOORS-SCREEN DOORS_CELLAR DOOR_PET DOORS-VARIOUS INTERIOR DOORS-ATTIC DOOR-BASEMENT DOOR-BATHROOM DOORS-BEDROOM DOORS-CABINET DOORS-CLOSET DOORS-FALLOUT SHELTER DOOR-TRAPDOOR-DOORS ON FILM-DOORBELL

To get a better handle on Doors, let us begin by approaching them in their various forms.

Things to consider:

I.) Open Doors are invitations.

2.) Locked Doors often dabble in the occult.

3.) Keys are the keys to proper operation.

4.) Sometimes opportunity knocks. Other times it rings the Doorbell.

5.) A Door is not a Door when Ajar.

6.) Knob placement. 


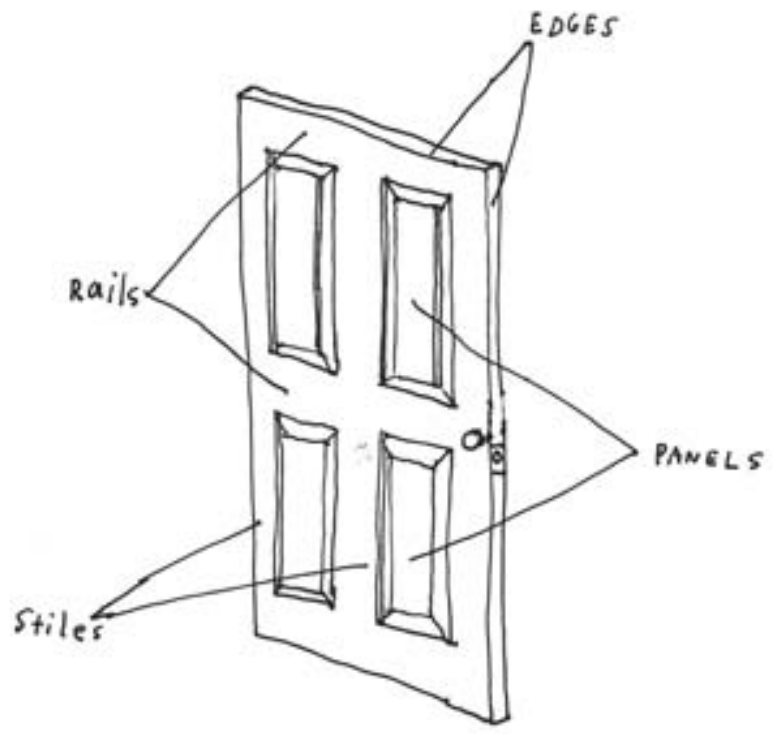

Figure 2 Less(on): Front Door sans Knob

\section{FRONT DOOR}

Usually preceded by Porch, the Front Door (also referred to as the "Alpha Door") is fastened to the beginning of the American Home. When American Homes are anthropomorphized in chil- 
dren's books, the Front Door is generally depicted as a mouth. It is the preferred Door of both Bible Believers and the ghosts of travelling salesmen and in most cases, welcome mats, flags, and mailboxes are positioned nearby. Oftentimes, it is the Door that one refers to in the phrase: "Answer the Door." Hence it accumulates more Annual Knuckle Precipitation than both the Back Door and Side Door combined. As the eminent matriarch of entranceways, the Front Door mothers us into the dwelling. Generally these "mothers" are wired with electronic chimes (See: Doorbells), which announce the arrival of "guests," and rarely as "guests" do we not find ourselves attracted to Front Doors. However, they remain apathetic to our arrivals. Yet this indifference only arouses us further. We yearn to enter them.

\section{BACK DOOR}

The Back Door (also called the "Omega Door") is the Front Door in reverse, except on Opposite Day when the Back Door impersonates the Front Door for a full 24 hours. Among American canines, it is favored due to its close proximity to the Backyard (See: Lawn School) or the Pet Door (See: Pet Door). Among provincial rednecks, Back Door guests are deemed best. Among pornographers, the Back Door is a clever marketing strategy. Among adulterers, the Back Door is the most common entrance and exit. However, the Back Door remains a mystery to Mormons and continues to elude most mailmen. The Back Door's favorite saying is, "If you gaze long enough into a backyard, the backyard will gaze back into you." 


\section{SIDE DOOR}

A Side Door (also known as the "Submariner") is secured to the American Home's hips. Commonly preceded by Driveway (See: Driveway Designs), it is unanimously championed for its efficiency and has a reputation as the German of American Doors. Groceries and meter men tend to pass through them with ease, and garbage cans and raccoons are prone to loiter in their vicinities. If an argument occurs in an American Home, the Side Door will remain neutral and provide an adequate escape route for the less aggressive party. "Right this way," it will say, because the Side Door is like that.

\section{GARAGE DOOR}

The Garage Door (also referred to as the "Automotive Tonsil") is the only exterior Door large enough for a Cadillac to enter. Usually operated by remote control, the Garage Door is said to possess keen psychic abilities. Not only does it sense your arrival prior to your arrival, it knows which pair of shoes you will wear to work ten minutes before you do.

\section{PATIO DOORS}

Patio Doors are notorious Window impersonators. Typically made of glass, these Doors resemble Picture Windows (See: Window Types) and are deceptively camouflaged by comparison. Not only do these bizarre Doors impersonate Windows, they slide back and forth, side-to-side; horizontal, and act real shifty. "Trust me," they seem to say. And never trust any remarks prefaced with those words. Also: Never trust a Patio Door. And: When a dead 
bird appears on your American patio, nine times out of ten, the Patio Door will not have an alibi.

\section{FRENCH DOOR}

ME: Knock, knock.

FRENCH DOOR: Je ne parle pas anglais. Partez tout de suite. $\mathrm{ME}$ : Je serai de retour.

\section{STORM DOORS}

Although Storm Doors (AKA "Element Deflectors") have long been ostracized by peers because of their inherently bad tempers, Storm Doors are the frontline doorographical defense against both natural and unnatural elemental tyranny. Not only do Storm Doors repel annoying insects, bad weather, and dangerous criminals, they also provide the American Home with both adequate ventilation and optimal visibility. Since, on a daily basis, Storm Doors sacrifice their well being for the sake of the greater home, and in turn receive little or no praise, they often become unhinged and develop self-destructive tendencies. Many become addicted to hardcore Door pornography, many more to drugs and alcohol. For this reason, a large number of Storm Doors turn to twelve step programs or Evangelical mega-churches for support. In fact, according to NACSA, in 200I, unhinged Storm Doors comprised $5 \%$ of the nation's Evangelical population. 


\section{SCREEN DOORS}

Screen Doors. I could give a shit about Screen Doors. They're always flapping in the American breeze and falling apart.

\section{CELLAR DOOR}

The Cellar Door is an exceptional Door despite the fact that it is the preferred Door for American junkies to knock on (Listen to: "Needle and the Damage Done" by Neil Young). Aside from its loose ties to heroin addiction, the Cellar Door is a marvelous Door. Stop. Say its name. Cellar Door. Doesn't that sound wonderful? Cellar Door. Ah. Aside from being blessed with a beautiful name, the Cellar Door is unique because it opens vertically rather than horizontally. Also: (See: Basement Door) it opens to Steps (See: Twelve Steps).

\section{PET DOORS}

A Pet Door is a Door within a Door. However, upon further inspection, it does not appear to be a Door at all, but rather a spring-loaded flap mounted to the zenith of an opening cut into the lower portion of an Exterior Access Door, thus enabling American pets to wander in and out of the American Home at their convenience. The Pet Door raises certain moral and philosophical questions in the Doorographical community. Is a Door a Door if a human being cannot fit through it? Is a Door a Door if it does not have a knob? Is it wrong to destroy a Pet Door after the tragic death of a pet? These questions remain unanswered. 


\section{VARIOUS INTERIOR DOORS}

Various Interior Doors (AKA VIDs) are found in a variety of locations throughout the American Home, each with a specific function.

\section{ATTIC DOOR}

Since days flip past listlessly in the back catalogue collecting dust (See: American Attics), the Attic Door is often considered a portal to the past, an entranceway to a dirtier time and place where memories occur in boxes. The Attic Door is less of a Door and more of a roped hatch cut into the ceiling, sometimes a wall, which if pulled properly will give way to Steps (See: Twelve Steps). Each step will take you closer to your childhood, yet somehow you will maintain your status in the municipal phone book. As previously mentioned, the Attic Door is shy a knob and keen on string. Give it a pull. Your past anticipates your presence.

\section{BASEMENT DOOR}

Favored by American horror directors, the Basement Door separates the American Home into different attitudes. The underground attitude (See: American Basements) is the preferred Bong Room by American stoners, so the Basement Door (AKA the "Debasement Door") acts as the principal aroma sentinel. Aside from the Attic Door and the Cellar Door, the Basement Door is the only other domestic Door that opens to Steps (See: Twelve Steps). The Basement Door is often considered the creepiest VID, and for good reason too, because, according to NACSA, in five homes out of ten, strange things occur behind it. 


\section{BATHROOM DOORS}

Initially designed as an architectural deodorant, these Doors functioned for 5.9 decades as the Chief Odor Guards of American Homes-protecting occupants' noses from olfactory disturbances. However, this changed dramatically in 1969 with Antonio Lysol's groundbreaking invention of the portable, pine-scented aerosol canister. After Lysol, Bathroom Doors were effectively relieved of their primary duties. But when one door closes another opens. Nowadays, Bathroom Doors proudly serve as domestic privacy shields; reliable structures for compulsive masturbators, bashful defecators, and wayward urinators to hide behind.

\section{BEDROOM DOORS}

Bedroom Doors obstruct visible signs of fornication. Because of this essential function, the Bedroom Door (AKA "Cupid's Flap") is the most revered door of the Various Interiors. It is a Door's Door, as well as a Doer's Door. Americans get made behind these Doors. They also get naked.

\section{CABINET DOORS}

Impostors.

\section{CLOSET DOORS}

Characterized by its close relationship with the Closet, the Closet Door (AKA "Latent Homosexual Dreamcatcher") is perhaps the most enigmatic of domestic Doors. What the Closet Door does 
not say is oftentimes more telling than what it does. It beckons people inside only to eject them. When a person enters a Closet Door, they are one way. When a person exits a Closet Door, they are another. For this reason, we must consider the Closet Door a magical partition, for it separates Truth from Reality, Reality from Truth, and attempts to merge the two together.

\section{FALLOUT SHELTER DOOR}

Found in 50\% of American Homes in the state of Utah, as well as I00\% of the American Homes of U.S. Senators, the Fallout Shelter Door is the gateway to a post-apocalyptic orgy of straw men (Think: "Mad Max for Mormons and the Power Elite, then try to remove the stain that such an image will produce.").

\section{TRAPDOOR}

The Trapdoor is also known as a "Secret Passage." Trapdoors are the best-kept secrets of American Homes. All homes have their secrets, but American Homes in particular like to gossip. A great place to gossip is inside of a Panic Room (See: Secret Rooms). 
18 Ryan Ridge

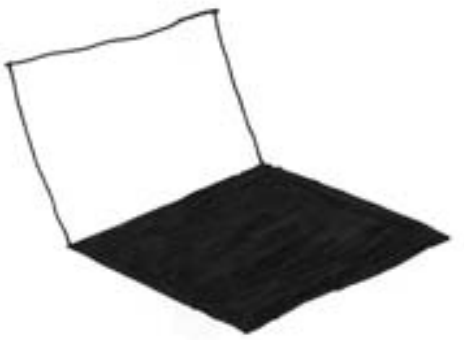

Figure 3 Trapdoor Warning: Don't fall for the trappings of the Trapdoor. 


\title{
DOORS ON FILM
}

\author{
Sliding Doors \\ The Door in the Floor \\ The Seventh Door \\ The Golden Door \\ Behind the Green Door \\ The Doors
}
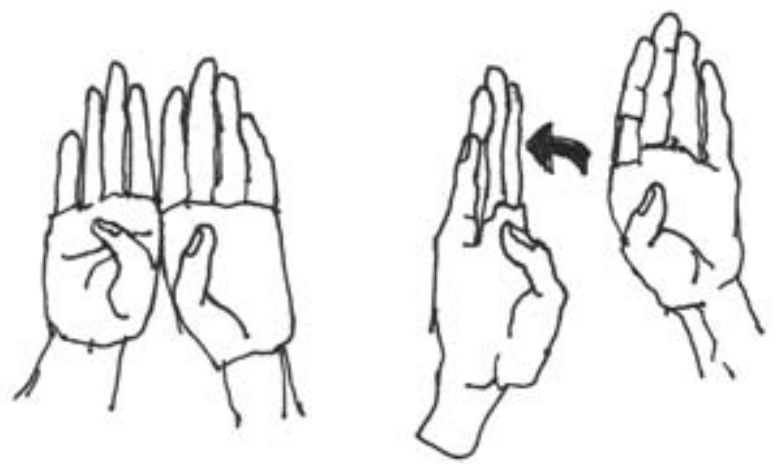

Figure ${ }_{4}$ Open Sign: Open Door in American Sign Language 


\section{DOORBELL}

Necessitated by centuries of sore knuckles, the Doorbell (AKA "Home Larynx") is a magical, melodic button, located around the summit of the (front) Doorknob. If pushed properly, the Doorbell will conjure cryogenic housewives from Benzo dreams. If pushed repeatedly, angry septuagenarians may emerge with golf clubs. If a Doorbell rings and no one is home, a tree falling in a forest makes a beautiful sound. 


\title{
WINDOW TYPES
}

\author{
AWNING-BAY-BOW-CASEMENT-DORMER- \\ DOUBLE HUNG-EGRESS-FIXED-FRENCH-HOPPER- \\ JALOUSIE-PICTURE-REPLACEMENT- \\ SINGLE HUNG-SKYLIGHTS-TRANSOM- \\ VARIOUS WINDOW ENHANCING DEVICES- \\ AWNINGS-BLINDS-CONCERNING CURTAINS- \\ SCREENS-WINDOW SILLS- \\ FRAMES-ADDENDUM-THE QUESTION
}

Before discussing the different varieties of Windows and their various accouterments, it should be noted that we typically do not look at the Windows in our American Homes-we look through them, beyond them, everywhere but at them. This is in spite of their aesthetic beauty. This is a testament to their functionality. This is also a sadness. Take a moment today and examine one of your Windows. What is it that you see? Smudges, fingerprints, watermarks, bullet holes? Look closer. In the right light, you might see yourself.

Things to consider:

I.) Windows are one of the central differences between American Homes and American Prisons.

2.) Broken windows are referred to as "Windowers."

3.) When American Homes are anthropomorphized in children's books, Windows are generally depicted as eyes.

4.) The word Window is derived from the Nordic word "vindauga," which literally means "Wind Eye." 
5.) When a redneck says "Window," it sounds like he's saying: "Wind Door," which actually sounds more accurate.

6.) Open Windows are invitations to the wind.

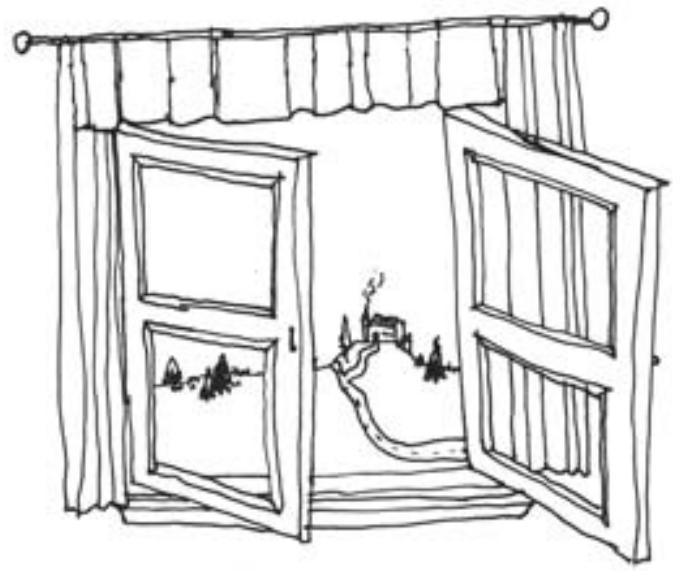

Figure 5 An Invitation: Come on in, wind. 


\section{AWNING WINDOWS}

Awning Windows (Also called: Yawning Windows) tend to open whenever American Homeowners are bored, which, according to NACSA, occurs during 68\% of commercial breaks. Opening an Awning Window is referred to by leading Windowologists as "Yawning" and this act can potentially set off a chain reaction throughout the neighborhood. Next time you open your Awning Window, try this simple experiment: Go out onto the Lawn and watch how many other tired American Homes begin yawning.

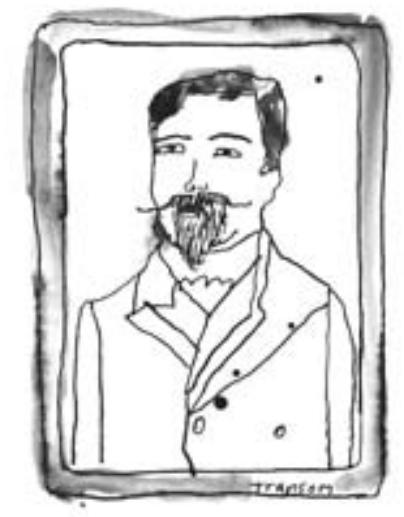

Figure 6 Transom: The founding father of Windowology, Theodore Transom. 


\section{BAY WINDOWS}

Here I am, sitting on the dock of the Bay Window: wasting time.

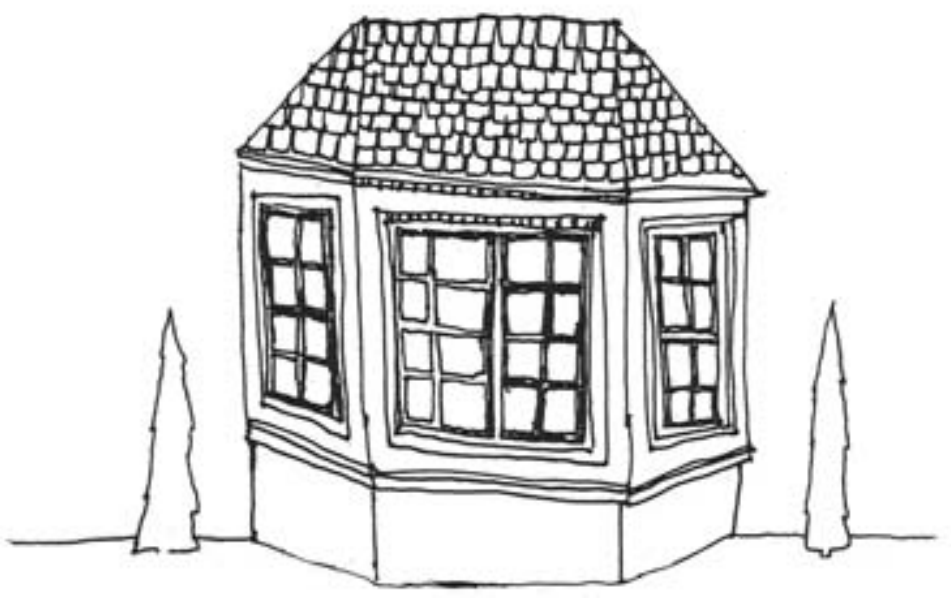

Figure 7 Bay Window: A place where I don't mind wasting time, alone or with you. 


\section{BOW WINDOWS}

Bow Windows (Also nicknamed "Elbows") jut out from American Homes not unlike Bay Windows (See: Bay Windows) but feature more windowed sections which converge to form an elegant, elbowed curve. These bonus sections open up to the Elements (Think: Prison Wind, Cloud Quakes, Purple Rain, etc.) making Bow Windows (AKA “Archery Ranges") ideal places for hopped-up American Homeowners to sit and take target practice at Potential Intruders (See: Apartment Dwellers, Missionaries, Jealous Cops, and The American Homeless).

\section{CASEMENT WINDOWS}

Hung solo or in tandem, Casement Windows (AKA "American Home Ventilators" or "AHVs") open themselves fully to the world while sending RSVP's to the breeze. AHVs are sidemounted and operated via interior Windowkinesis cranks. Everyone knows that the undercarriages of American Homes are referred to as Basements (See: American Basements), but a little known fact about American Homes is that the floors above Basements are technically called Casements, hence Casement Windows. Open them up and scoop in the wind. I don't know about you, but I, for one, breathe easier knowing that Casement Windows exist.

\section{DORMER WINDOWS}

I figured Dormer Windows were just Windows which college students looked out of, but I was wrong. According to NACSA, 33\% of what we think we know is wrong. Dormer Windows are, in fact, 
second-story eyelids that allow the upper half of the home to see the light, even in these dark times.

\section{DOUBLE HUNG WINDOWS}

When a man is double hung it is one thing, but when a Window is double hung it is two things. Double Hung Windows (AKA "Siamese Twindows") consist of dual glass sashes that slide vertically past one another. Double Hung Windows are more bang for your buck. Two windows for the price of one. For more information read about its predecessor (See: Single Hung Window).

\section{EGRESS WINDOWS}

Egress Windows (AKA "Emergency Emergences") act as safety valves for American Homes, devices for transporting women, children, pets, and Homeowners away from certain death. Late at night, Egress Windows are the preferred entrances and exits of American teenagers entrancing and exiting one another.

\section{FIXED WINDOWS}

The word "fixed" implies past brokenness, as in repaired. But in the case of Fixed Windows they are in need of repair. They are "fixed" only in a corrupt sense. Try and open a Fixed Window sometime and you will see: the only way to open it is to break it. In that sense, a Fixed Window is not altogether different than the human heart. 


\section{FRENCH WINDOWS}

Found in ${ }_{3} 3 \%$ of American Homes (Source: NACSA), French Windows (AKA "Benedict Arnolds") aren't actually Windows at all, but Doors (See: French Doors). NOTE: From 2003 to 2005, French Windows were referred to as "Freedom Windows."

\section{HOPPER WINDOWS}

Hopper Windows (Also referred to as "Dennises") are the wildest Windows. Structurally, they are quite similar to Awning Windows (See: Awning Windows), except that they hinge at the bottom rather than the top. Because of this unique design feature, Hopper Windows unabashedly invite the Elements into your American Home and feel little or no remorse about it. If you ask a Hopper its opinion on the matter, it will invariably respond by not responding. And silence says so much.

\section{JALOUSIE WINDOWS}

Jalousie Windows (Also called "Instant Noir") are comprised of parallel glass slats stitched horizontally throughout a window frame. The slats can be angled in such a way that the light falling into your American Home will make your American Home seem just like the stylish set of a hard-boiled Hollywood crime drama. Perhaps you're wondering why you would want your American Home to look like the set of a hard-boiled Hollywood crime drama. Perhaps this seems creepy to you? Well, no need to investigate it any further: it is creepy and Jalousies are the creepiest of the various Window Types. After all, what rhymes with Jalousie? 
A: Jacuzzi. And nine times out of ten if you see a Jacuzzi there'll be a Jalousie nearby. I rest my case.

\section{PICTURE WINDOWS}

Picture Window is a zen koan. Can you picture window or do you only picture what is beyond window? To overlook a Picture Window is to look at the yard. This is a paradox. But try taking a picture of a Picture Window and putting it in a picture frame-a frame within a frame within a frame within a frame. This is not a paradox, but a French film. The failure of experimental cinema, in most cases, is a failure of perception. Ultimately, the problem with Picture Windows is the same. We fail to see the thing itself. But there is no success like failure. Bob Dylan said. And failure is no success. Remember: the first word in "window" is "win." Picture Window is a zen koan. Can you picture window or do you only picture what is beyond window?

\section{REPLACEMENT WINDOWS}

An American Homeowner replacing a Replacement Window is an act of revisionist history. Whenever a Replacement Window is replaced, a small piece of our past is erased. This happens all the time in the land of American Homes, yet most of us couldn't care less because we are inclined to such forgetfulness.

\section{SINGLE HUNG WINDOWS}

According to noted Windowologist Theodore Transom, Single Hung Windows "embody the Platonic essence of windows." They 
are the classicist's Window, the Window that comes to mind when you hear the word "Window." Close your eyes. Do you see it? Yes. There it is. Now open it up and open your mind to the possibility that this is the best day of your life.

\section{SKYLIGHTS}

Skylights (also referred to as "Sun Tunnels") are thresholds to the sky. During the Dark Ages travelling salesmen went door-todoor selling skylightbulbs. Later, in the primitive era of American Homes, Skylights were simply called "Shitty Roofs." "I believeth there is a gaping cavity in your roof, gentle neighbor," one colonist said to another. "Ah, but that is a Sun Tunnel," said the other. "I purchased it cheap from a Frenchmen. It adds natural light to my American Home!" The first colonist stepped back, considered it; "'ll be damned. Leave it to the French." 


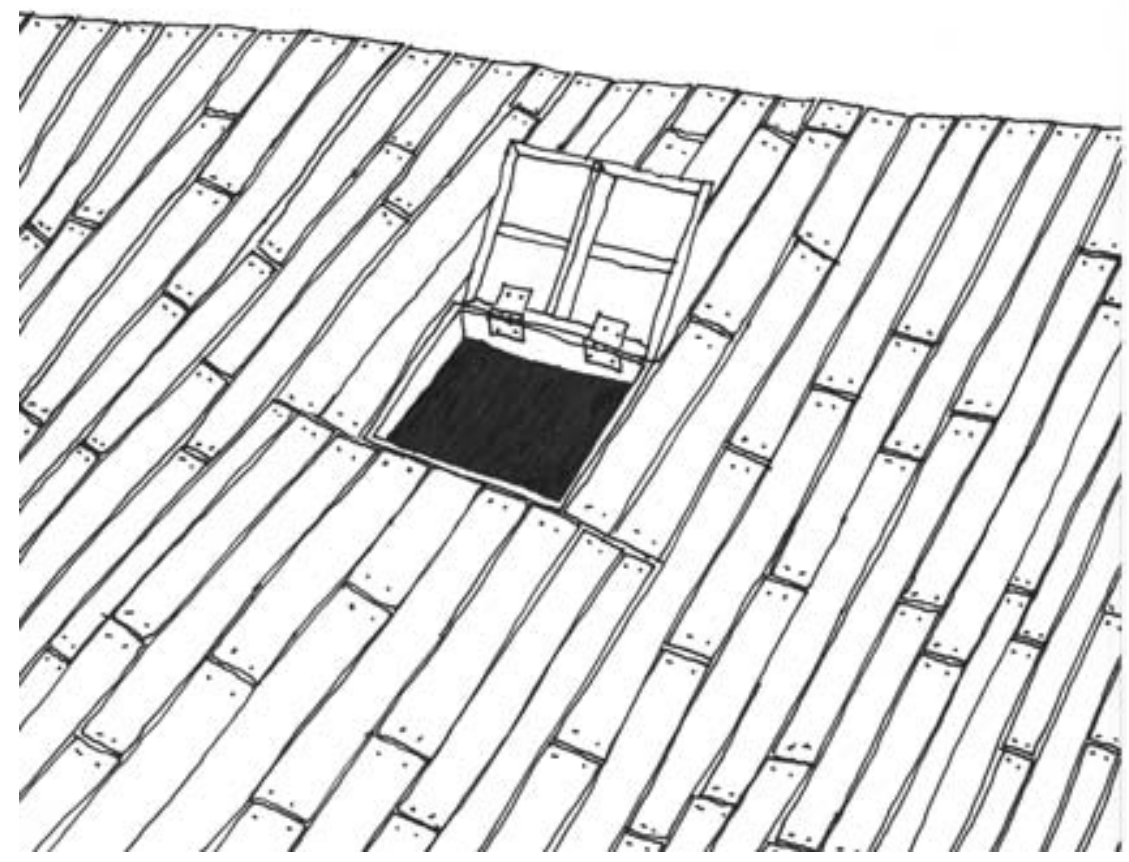

Figure 8 Skylight: Afternoon delight. 


\section{TRANSOM WINDOWS}

Transom (AKA "The Manuscript Depository") is the term for the little window above the Front Door (See: Doorographical Divisions). In the olden days, unpublished American authors used to toss their unsolicited manuscripts through the Transom Windows of unsuspecting editors' American Homes. Now, we use online submission managers and email instead, which is a very good thing, because according to NACSA, from the years 1865 through 1996 nineteen innocent editors were blinded or crippled by unidentified flying manuscripts.

\section{VARIOUS WINDOW ENHANCING DEVICES}

Various Window Enhancing Devices are added to increase/ decrease the functionality of Windows, each with a specific function.

\section{AWNINGS}

Awnings are woven (sometimes aluminum) hats worn by Windows to protect themselves from the sun and rain and sometimes snow. 


\title{
BLINDS (A-Z)
}

\author{
Ambition \\ Brise Soleil \\ Contour Drawings \\ Dates \\ Everest \\ Faux Wood \\ Gary Davis \\ Honeycomb \\ Illusion \\ Justice \\ Keri Hilson \\ Louvers \\ Minis \\ Night \\ Obsession \\ Persians \\ Quips \\ Rollers \\ Schools \\ Trust \\ Umpires \\ Venetians \\ Willie McTell \\ XML Schemas \\ Youth \\ Zebras
}




\section{CONCERNING CURTAINS}

Curtains are meant to be drawn. Use the space provided below to draw the curtains:

\section{SCREENS}

Screens are used to protect Windows from suffocating to death. They're also cut in dime-sized increments and used in American bongs as cherry guards.

\section{WINDOW SILLS}

A Window Sill is the flat part at the bottom of a Window Frame. A perfect place to put your feet if you're floored.

\section{FRAMES}

Windows are innocent I tell you! Innocent! They've all been framed!

\section{ADDENDUM}

Prison Wind-The breeze bouncing off American Penitentiaries is known as Prison Wind. When Prison Wind rattles the Windows of our American Homes, the very notion of human freedom is called into question. According to NACSA, twenty-three new prison cells are built each and every hour here in the land of American Homes. This statistic is meant to serve as a Window into our souls. While there is a soul in prison, we are not free. Said 
Eugene Debs over a century ago. Over a century ago. Debs. Pissing in the Prison Wind.

\section{THE QUESTION}

The question isn't: Why tint the Windows of your American Home? The question is: Why not? Although your house will be so much warmer, you'll feel so much cooler, which is so much more American. 


\section{AWAYWARD FUNCTIONS}

ROOFS-CHIMNEYS-GUTTERS-FURNACES_FIREPLACES

The Awayward Functions take unwanted things away from an American Home. 


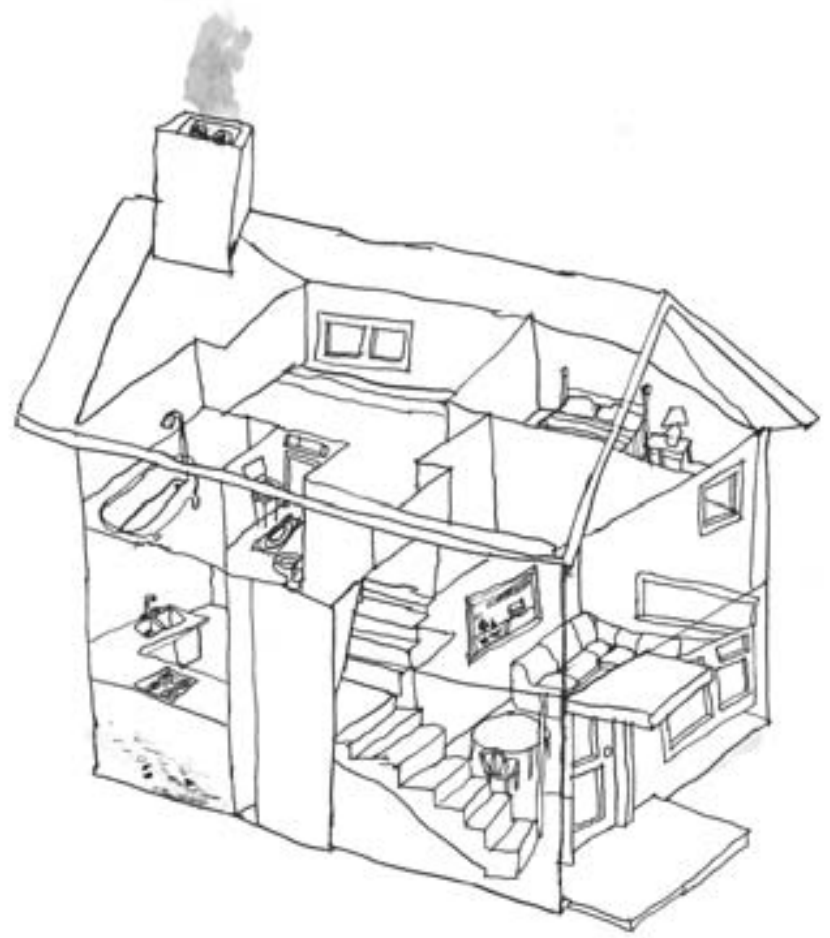

Figure 9 No Place Like Home: The Anatomy of an American Home

\section{ROOFS}

Roofs-flat or slanted-wooden and enchanted—slats, converging at an American Home's summit. Often shingled and frequently festooned by various ornaments: antennas, Christmas lights, Chimneys, Virgin Mary statues, weathervanes, and satel- 
lite receptacles, Roofs act as industrial-strength prophylactics, defending the dwelling from various airborne toxins (e.g., Angel Tears, Swine Flu Vomit, Nuclear Winter Dust, etc.), as well as a multitude of Mother Nature's own lesser-known miscarriages (e.g., Prison Wind, Cloud Quakes, etc.). Roofs (also referred to as "Mortgage Helmets") are magnets for alcoholic stepfathers, as well as the Working Poor. In 2002, Forbes Magazine named Roofs "The Absolute Worst Place to Earn a Living." This perhaps due to their precarious distance from the ground, as well as their heated relationship with the Sun. Roofs tend to be accompanied by Gutters (See: Gutters). Also: Chimneys (See: Chimneys). If a person is having an outstanding time at a Dance Party (See: Domestic Festivities) they may hoist both arms in the air and say: "Raise the Roof!", which means that person anticipates having an even more outstanding time in the near future. There is a certain variety of exhibitionist who enjoys having sex on Roofs. These people are called "Roofies." Roofs are also the place where Santa Claus parks his sleigh in children's imaginations.

\section{CHIMNEYS}

Chimneys most notably are the way in which American Homes send secret messages to other American Homes via smoke signal. One home may say, "I am a home. My name is I8I2 Winchester Street." And another home may respond: "So glad you are. My name is the Ridge Residence. Although we are connected by power-lines, I don't believe we've ever met." Aside from providing home-to-home messaging, Chimneys (AKA "Arson Averters") make it safe for people to set things on fire indoors. The places where people set things on fire indoors are called Fireplaces (See: 
Fireplaces) and are positioned at the base of Chimneys. Most Chimneys are bald, but some Chimneys wear hats to mask their baldness. These hats are known as Chimney Caps. The empty space inside a Chimney is called a "Flue." The empty space inside a "Flue" is called: "The Sound of One Hand Clapping." If you place your head in an unlit Chimney, you will hear the ashes of American trees discussing the death of the American forest. This is guaranteed.

Frequently Asked Questions Regarding Chimneys

Q: What is the sound of one hand clapping?

A: The sound of a chimney sleeping.

Q: Why do so many chimneys wear caps?

A: To conceal baldness. Also: to keep birds out.

$\mathrm{Q}:$ Is it all right to climb inside my chimney?

A: Yes, but one should measure both oneself and one's chimney before proceeding.

$\mathrm{Q}$ : Is it wrong to have sex with my chimney?

A: Yes, even if it feels right.

Q: My husband smokes like a chimney. How can I get him to stop?

A: Try cold turkey. Or: jelly beans worked for Ronald Reagan.

\section{GUTTERS}

Whether aluminum or galvanized, seamless or flawed, Gutters (AKA "Crap Vessels") do more than seize sky fluids, they also prohibit the home from over-ingesting a plethora of dangerous 
atmospheric contaminants, including but not limited to: Acid Rain, Purple Rain, and Stray Microbes. Often times Gutters will fill up with leaves and a variety of other tree debris. Hence Gutters must be emptied and sanitized at regular intervals, preferably monthly. "Cleaning the Gutter" is an ancient initiation rite passed down from American fathers to their pre-manly sons. In America, once a boy has climbed a ladder and scraped detritus from the Crap Vessel, that boy is no longer a boy-he is a man. The term "Cleaning the Gutter" is also an American euphemism for a sexual maneuver. And sometimes, when a person possesses a dirty mind, a person with a cleaner mind will say to that person, "Hey Jim, get your mind out of the Gutter!"-which is a strange thing to say if you really think about it, especially if your name isn't Jim.

\section{FURNACES}

If Furnaces were removed, as winter weather worsens we would witness American Homeowners shivering in Living Rooms, dialing Thermostats to no avail and exhaling smoke clouds. When communicating with furnace repairmen it should be done with a fiery tongue. A good Furnace is not unlike a good Father. It will project warmth and encourage us to relax.

\section{FIREPLACES}

Where there is smoke, there is a Fireplace. A Fireplace is an outdoor heat decoration transposed indoors. The ferocious tiderips of the blue night in the Fireplace bring to an American Home heat that causes logs to pour gray gulfs. Hence the Fireplace is 
like a person with emphysema or whooping cough. Or, from an aerial perspective, it is a giant straw sucking smolders cloudward. Metaphorically, the Fireplace is glowing sunbirds, phoenixes-rising from the ashes of American forests: smoke / fire / place. If a smoker sits next to a Fireplace, the smell of their cigarette will vanish. If a Fireplace sits next to a Fireplace, call the architect and demand your money back on your American Home.
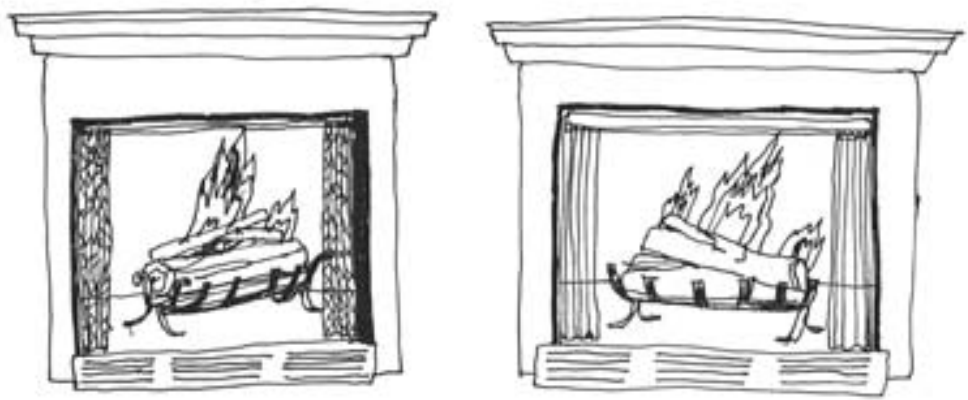

Figure ro Double Fireplace: Time for a refund! 


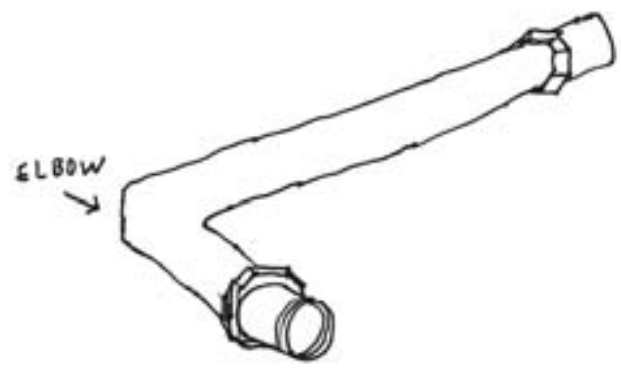

This is not a pipe. 


\section{ANOTHER THING CLARENCE SAID}

I just remembered another thing Clarence (See: Clarence) said that night on his Front Porch. He said: Many of the founding fathers were Freemasons. I said: I didn't think that was true. I thought only 10\% of the men who signed the Constitution were masons. He said: Try more like 33\%. Does that number mean anything to you? No, I said. Are you a Freemason? Hell no, he said, and I'm not a founding father, either, but I am a Stairmaster, I3th Step. In terms of secret societies, we are by far the most secretive. Try and find us on the Internet and you'll find nothing, not a thing, but we exist, and we are everywhere. We are like God in our omnipotence and we play our air guitars like motherfucking champions (See below: as above!).

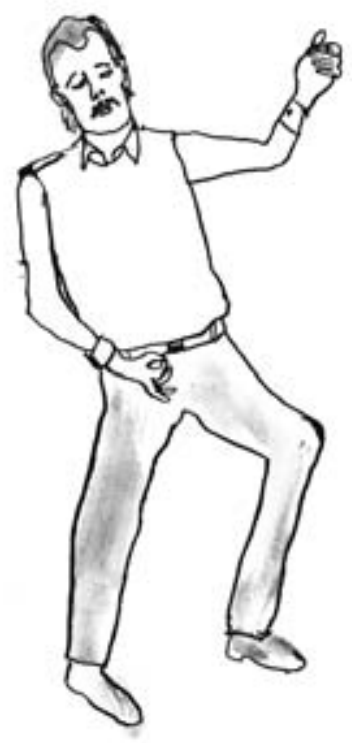




\title{
STAIRCASE STUDIES
}

\author{
STAIRWAYS-STAIRMASTERS-BANISTERS- \\ LANDINGS-TWELVE STEPS
}

There are multiple ways to use Stairs. This is why we call them Stairways.

\section{STAIRWAYS}

A Stairway is a metaphor for life, but life is not a metaphor for a Stairway. That would be dumb. Stairways (AKA "Enemies of Infants \& Elderly") are vertical bridges found in American Homes. Usually consisting of twelve steps (See: Twelve Steps), Stairways are the most common routes between two Floors. Certain types of American Homeowners skip Steps when traversing Stairways. Others take them one at a time. Typically, when an American Homeowner is British they will refer to a "Stairway" as a "Staircase." According to NACSA, I3\% of American parents have installed Riot Stairs in their American Homes in case a teenage riot breaks out unexpectedly.

NOTE: Sometimes Stairs take flight. Flying Stairs are referred to as Elevators and are rarely found in American Homes.

\section{STAIRMASTERS}

Stairmastery is an American fraternal society that arose from the ashes of American Folk Homes (Think: Wood-Frame Guthries). Founded upon Avant-garde architectural principles and '7os 
heavy metal, Stairmasters abide the motto: The higher the American Home, the closer the American Homeowner is to God. Hence Stairmasters advocate Stairways in every member's American Home, regardless of functionality. They also advocate drugs. One of Stairmastery's most controversial initiation rituals is called "The Solo Stairway to Heaven" in which the blindfolded initiate walks up a flight of Stairs masturbating while listening to a six minute Jimmy Page guitar solo. The initiate is then required to come on the Landing (See: Landings) and to refrain from touching the Banister (See: Banisters). Stairmasters are also said to be virtuoso air guitarists.

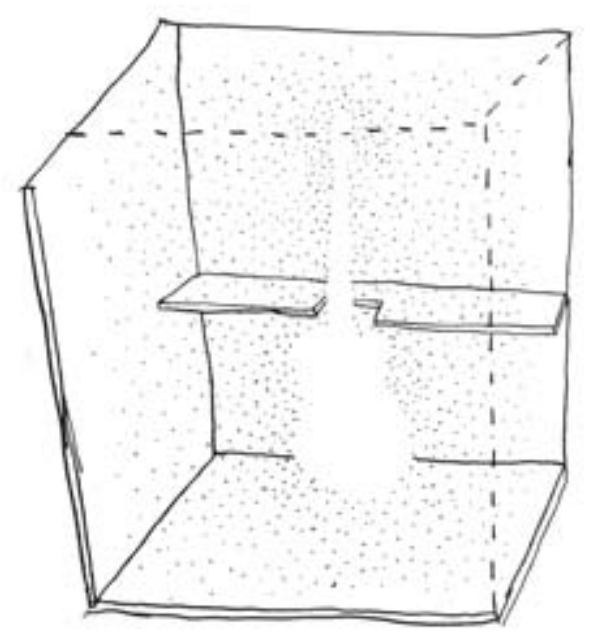




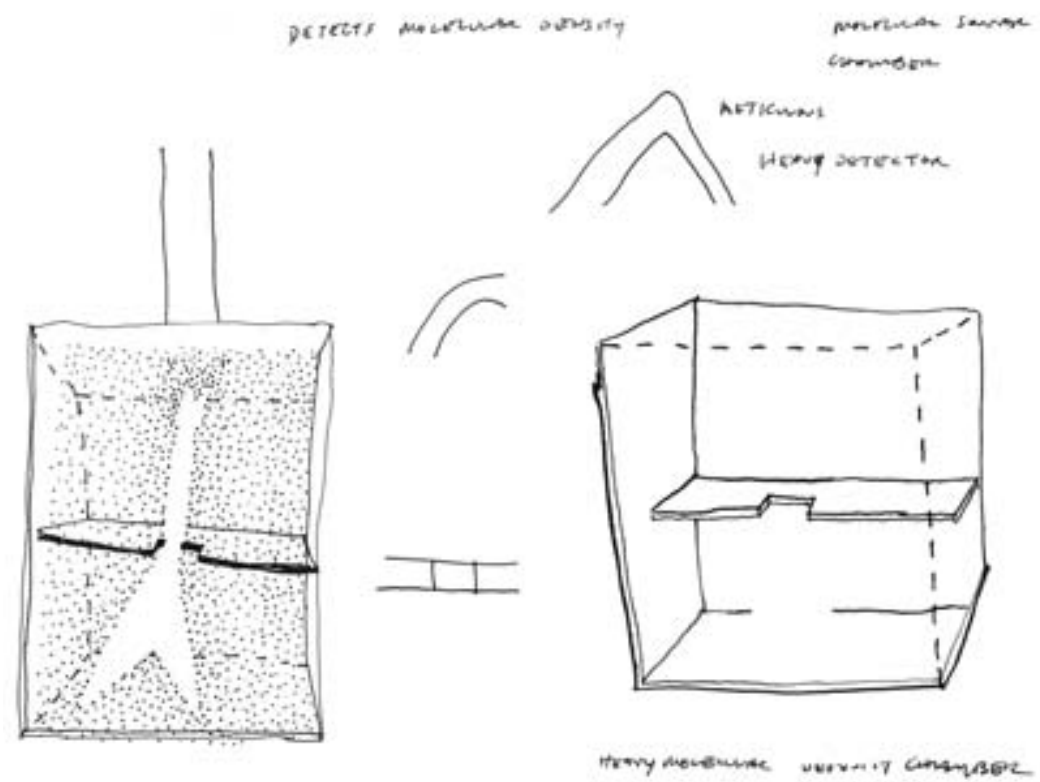

Figures II \& I2 (St)Air Guitar Cases: 3 Stairmasters' Air Guitar Cases.

\section{BANISTERS}

To think I spent my youth mistaking Banisters for rides. It wasn't until I was grown and joined a support group that I realized Banisters were there to prop us up and break our falls. 


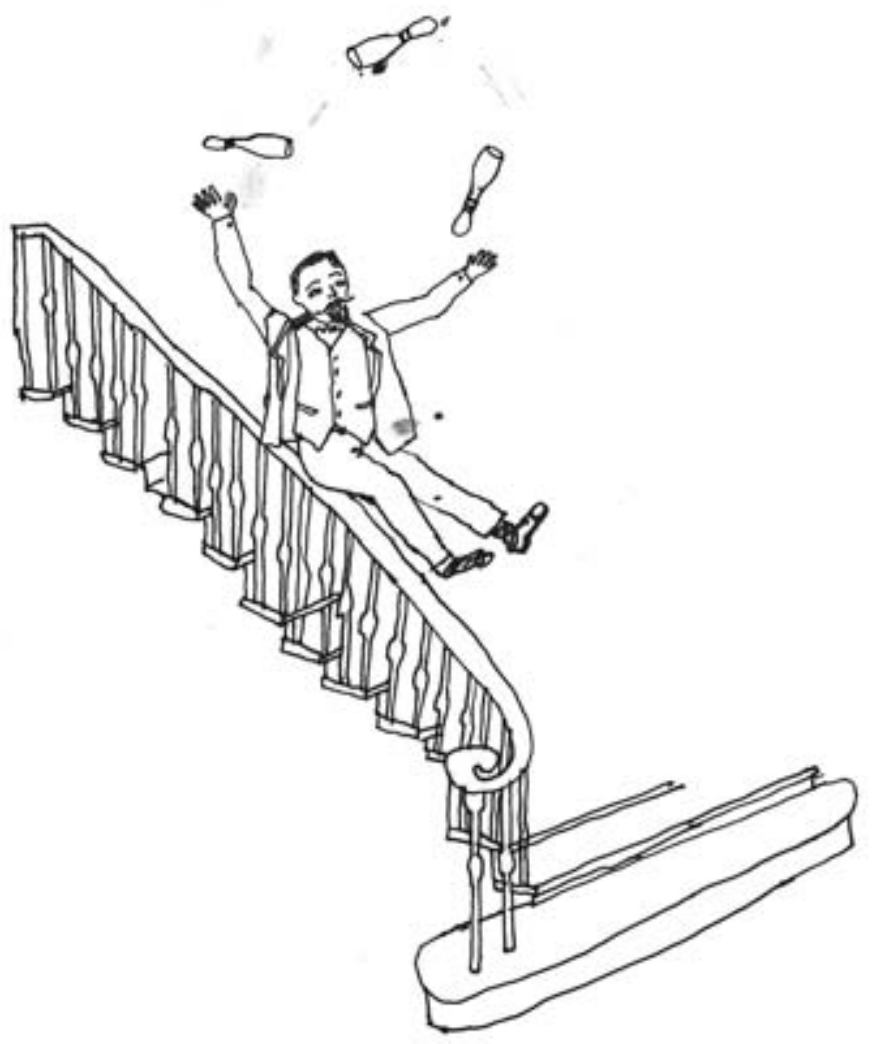

Figure ${ }_{33}$ Forget Lightning: A juggling Theodore Transom "Rides the Rail."

\section{LANDINGS}

Stairmasters shape Stairs to and from the deafness spoken in the wind. Invitations. Incantations. Spells. As the downstairs builds up and the upstairs stares down. And unknowingly, the sound of feet. On Landings. The elderly tumbling from reckless flights. 
Toward landings. Photographs of teenagers on prom night. And the deviations from the deafness spoken in the wind. On Landings. Toward Landings. Landings (AKA "Crash Pads") are the end results of Stairs you thought would probably never end.
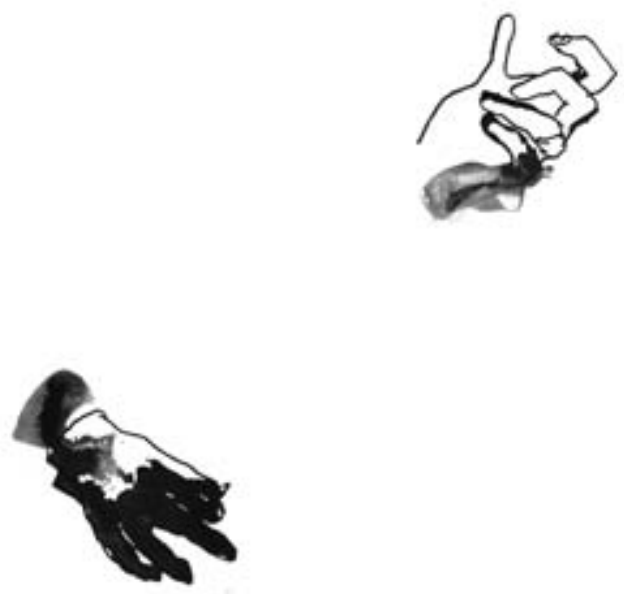


\section{TWELVE STEPS}
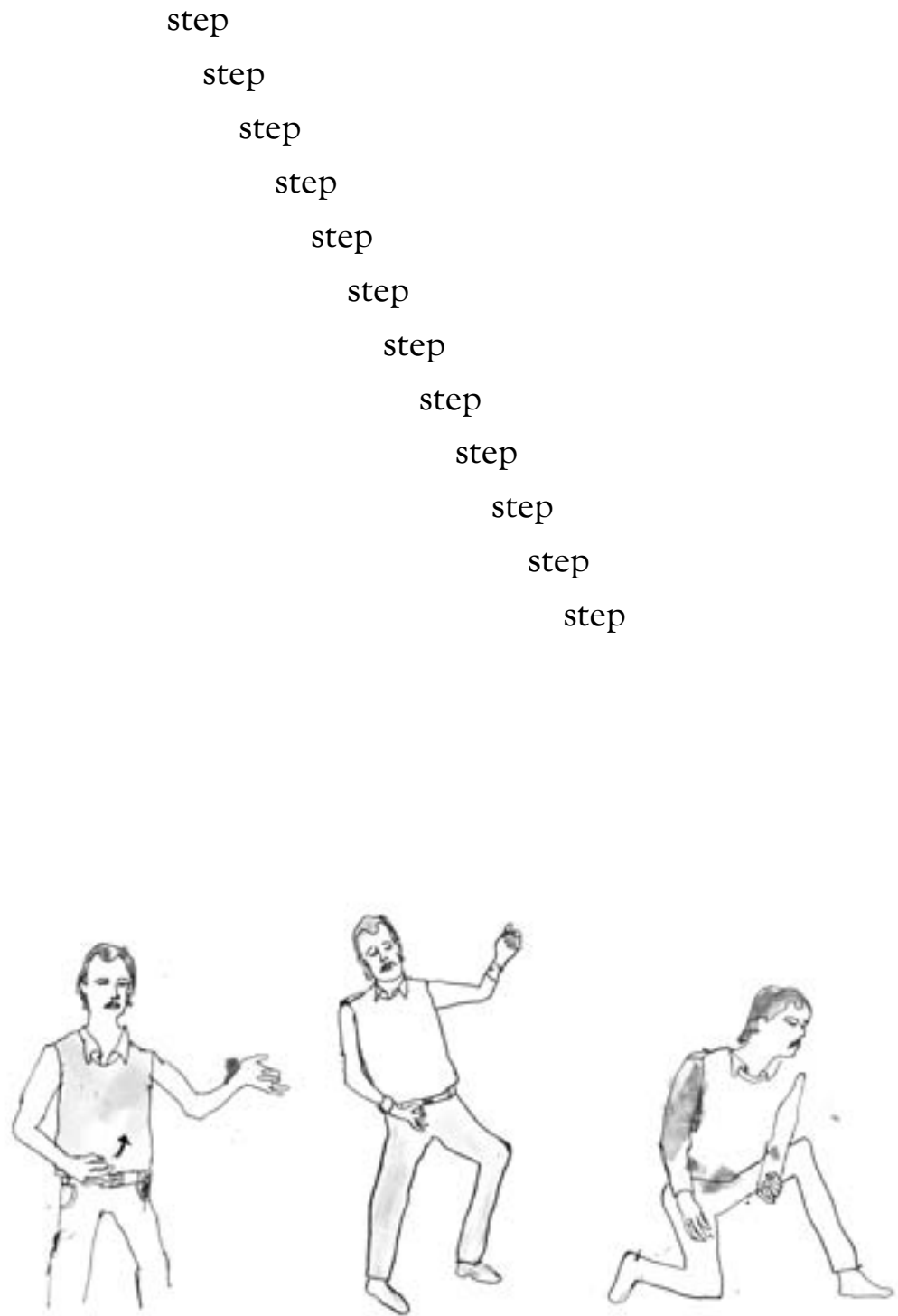

Figure ${ }_{4}$ Air Guitar Solo: Clarence plays Crazy Train. 


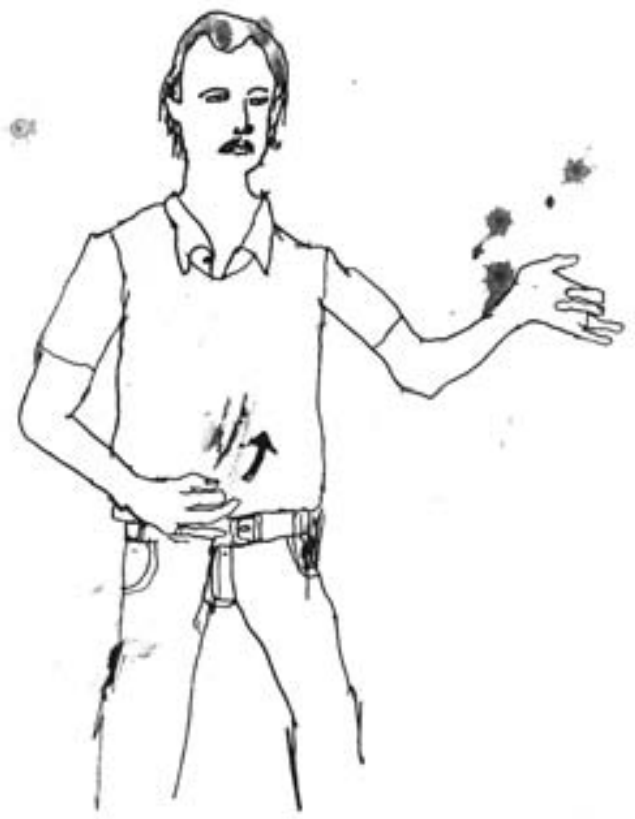

“One man's Stairway to Heaven is another man's Staircase to Hell.” —Clarence 


\section{GARAGEOLOGY}

GARAGE-GARAGE SALES-GARAGE SALES-GARAGE SAILS-CARPORTS-AMERICAN SHEDS-GARAGEOGRAPHICS

\section{GARAGE}

Preceded by Driveways (See: Driveway Designs) Garages (Also referred to as "Automotive Altars") are car sanctuaries in American Homes where automobiles enter, rest, and are worshipped on weekends. Since most American automobiles are powered by foreign oil it is necessary for the Land of American Homes (AKA "U.S.") to battle the Land of Foreign Oil (AKA “Them") in order to safeguard the economic sanctity of our oil-driven car culture. Garages (or "Riff Palaces") are havens for teenaged guitarslingers as well as middle-aged dreamers. According to NACSA, 50\% of one-hit wonders are composed in American Garages. Also: 99\% of that $50 \%$ are songs utilizing the same three chords (I, IV, V). That's ingenuity for you. Garages are the places where wildly successful American entrepreneurs start out. Tragically, they're also the places where severely depressed American Homeowners end up. R.I.P.

\section{GARAGE SALES}

Name applied to black market items sold and resold (sometimes traded) by American Homeowners in a tax-free zone. 
NEIGHBOR: What are you doing?

HOMEOWNER: Having a Garage Sale.

NEIGHBOR: How much for the husband?

HOMEOWNER: I only accept trades.

NEIGHBOR: Will you take my husband for yours?

HOMEOWNER: Does he snore?

NEIGHBOR: No.

HOMEOWNER: Deal.

\section{GARAGE SALES}

Name applied to Garage when a price tag is applied to Garage.

\section{GARAGE SAILS}

Name applied to Garage when a Mainsail is applied to Garage. 


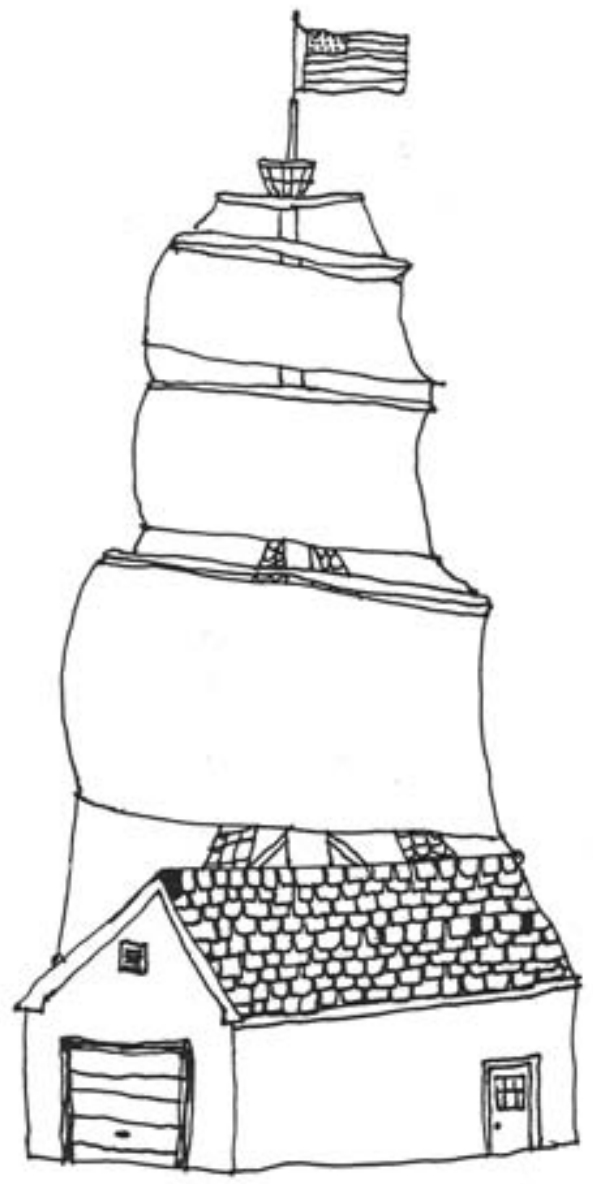

Figure ${ }_{5}$ Garage Sail: Let's sail sale into the sunset of this new American century. 


\section{CARPORTS}

Invented by architectural genius Frank Lloyd Wright between his second and third marriage, Carports are roofed structures without walls. They provide American automobiles with limited but sufficient Element Deflection.

FRANK LLOYD WRIGHT: A car is not a horse. It doesn't need a barn!

FRANK LLOYD WRIGHT'S FOURTH WIFE: Your fly is down.

\section{AMERICAN SHEDS}

Spiritual structures used for storage and hobbies and the beating of disobedient children. Often found in Backyards, American Sheds are not dissimilar to American churches in that they provide comfort and solace to American Homeowners during these trying times in the Land of American Homes. Go and spend some time alone in your American Shed today. The light in there may shed light on a few things and you'll feel better afterward. If you don't own a Shed, go and break into someone else's. It's what I do. In fact, I'm sitting in Clarence's Shed right now, conducting interviews with Mike, Eric, Alice, and Jared for some supplementary materials (See: Garageographics). 


\section{GARAGEOGRAPHICS}

\begin{tabular}{|c|c|c|}
\hline Mike & Eric \& Alice & Jared \\
\hline $\begin{array}{l}\text { Mechanic, Self- } \\
\text { employed }\end{array}$ & Cop \& Nurse & Corporate Spokesperson \\
\hline Favorite Band: Mike & Favorite Band: Alice & Favorite Band: Fatboy \\
\hline$\&$ The Mechanics & in Chains & Slim \\
\hline Parks his Pontiac in a & Park their 2.2 cars in & Parks his fleet of Hummers \\
\hline One Car Garage & a 2.2 Car Garage & in a Six Car Stable \\
\hline
\end{tabular}




\section{DRIVEWAY DESIGNS}

THE STRAIGHT \& NARROW-THE AMERICAN EVOLUTION-THE TEPEE-THE FIGURE 8-THE HIDDEN DRIVE

Private roads that deliver us to and from our American Homes, Driveways serve as access from American Homes to the rest of the country. Over time, many Driveways-like many Americans_fall apart and break down. Some seek repair. Others remain cracked. Below is an aerial representation of the five most common American Driveway designs, followed by brief expositions.

\section{[Aerial Representation]}

- Design I: -

- Design 2:-O

- Design 3: $\wedge$

- Design 4: $\infty$

- Design 5:

Design I-Illustrates a classic and careful American Driveway style known as "The Straight \& Narrow." This simple design incorporates a remarkably straightforward construction and appeals to American Homeowners who uphold the principles of our national Constitution and abide by at least eight of the Ten 
Commandments-folks who believe that the quickest and most moral way between two points is a straight line.

Materials_Solid: Includes Asphalt, Blacktop, Concrete, Pavement (often accompanied by Flags, Fear, and Crosses)

Design 2-Depicts an elegant and extravagant American Driveway style called "The American Evolution." This expensive design offers American Homeowners a scenic homeward approach and an expansive turning radius. The landscaped center of The American Evolution is referred to as an "island." Often gangs of cherubic statues pissing recycled rainwater into marble birdbaths populate these "islands." More often they are places where American pets shit (See: Awayward Functions).

Materials-Mixed: Includes Custom Bricks, Cobblestone, Marble (often accompanied by Alligator Moats, Armed Guards, and Electric Fences)

Design 3-Depicts a discriminatory American Driveway style called "The Tepee." Whereas the preceding Driveways display functionality and wealth, The Tepee (AKA "The Trail of Tears") represents the opposite. Most Tepees consist of one primary lane that splits into two (or sometimes several more) American Homes. Often found in rural and underpopulated aspects of Oklahoma and Arizona, The Tepee conserves resources and doesn't impose itself on the land. Rather, this design imposes itself on American Homeowners.

Materials_Aggregate Surface: Includes Gravel and Bones (often accompanied by casinos)

Design 4-Depicts a popular American Driveway style known as "The Figure 8." Not surprisingly, NASCAR dads and demolition derby enthusiasts favor this intense and elliptical Driveway 
design. When an American Homeowner installs a Figure 8 in his Front Yard, he means business. This design is not for the faint of heart.

Materials—Solid: Includes Asphalt, Concrete, Pavement (often accompanied by Cheap Beer and Second Amendment Enthusiasts)

Design 5-Shows a stealthy American Driveway style called "The Hidden Drive." This camouflaged American Driveway design manages to elude most guests and GPS. One wonders: "What do these Driveways have to hide?" According to American Driveway Magazine, The Hidden Drive is quite popular amongst Occultists, Militia Members, and former high-ranking Neocons.

Materials-???

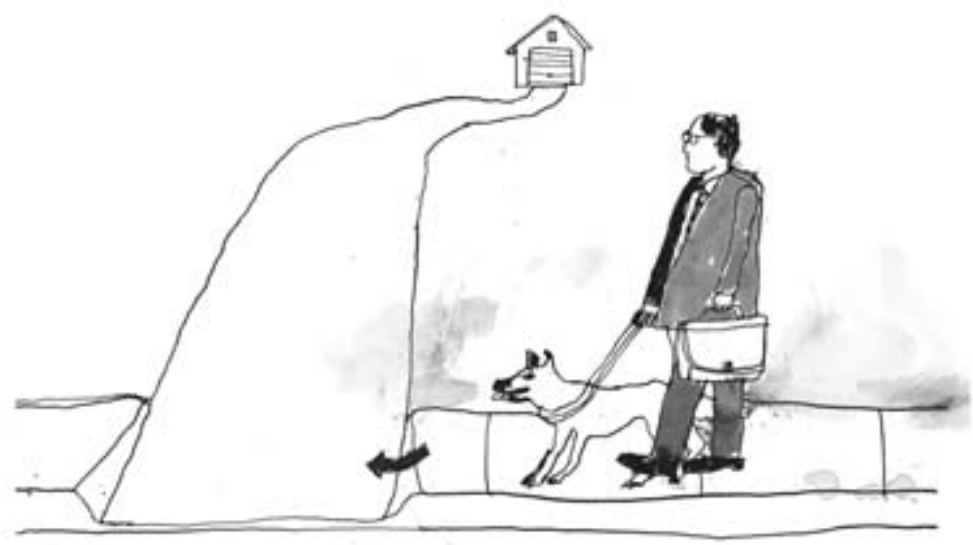

Figure 16 Pedestrian Considerations: Pedestrian considerations are hardly pedestrian considerations and should be taken into account regardless of the Driveway design scheme. 


\title{
DOMESTICITY CUBED
}

\author{
WALLS-FLOORS-CEILINGS
}

\begin{abstract}
WALLS
Mode of room and occupant division, partition. Method of ceiling support. Walls (AKA "Babylon Shields") fortify and defend the dwelling from various scourges and contagions. Not unlike cells in the human body, Walls are the basic building blocks of American Homes. Without Walls, American Homes would assuredly fall. When an American Homeowner places his back against a Wall, he may be suddenly overwhelmed by hopelessness and dread-in which case said Homeowner may turn around and bang his head against said Wall until he feels more optimistic. According to NACSA, these occurrences happen approximately every thirty-seven seconds in the Land of American Homes.

NOTE: Should you ever see strange handwriting on the Walls of your American Home (perhaps the phrase "die pig" written in uncooked bacon), vacate the premises immediately. Either that or take shelter in a secure location (See: Panic Room).
\end{abstract}

\section{FLOORS}

Groundward surface of room. Often wooden, sometimes carpeted or tiled. Where occupants walk and sometimes moonwalk. Also referred to as "Debris Magnets," Floors attract dirt and dust and other household detritus such as food and fingernails and 
pretty much anything broken or broken-hearted. When an American Homeowner is feeling hilarious, it is customary to drop to the Floor in convulsive laughter. When an American Homeowner is feeling afraid, it is customary to hit the floor. When an American Homeowner is feeling intoxicated it is not uncommon to mistake the Floor for a Bed (See: Beyond Bed Bath $\mathcal{G}$ Beyond). On a separate but somewhat related note: Floorganic Chemistry is a discipline within chemistry involving the scientific study of the structure, composition, and cleaning practices of domestic Floors. It is said that Floorganic Chemistry was born in a Chicago basement when Ives W. McGaffey invented the first hand-pumped vacuum cleaner. Other famous Floorganic Chemists include: Archibald Shag (Milwaukee, WI, the Inventor of the Shag Carpet) and Englishman Frederick Walton who designed the first linoleum floor in 1860.

\section{CEILINGS}

Upper boundary of a room. Places where occupants stare when they are drunk on drugs or religion (or sometimes just bored). Also referred to as "Sky Hoods." Ceilings are perpetual provocateurs, arrogant reminders of our own failures and limitations. If an American Homeowner hits the Ceiling, nine times out of ten the Ceiling has done something to deserve it.

NOTE: If you find yourself living in an American Home with a glass Ceiling it is recommended to move into a different American Home.

NOTE: If you find yourself in an American Home with a glass floor, you are probably not in an American Home at all. More likely you're on a fishing boat like myself. Me? I am way out at sea, 
drinking whiskey, and admiring this crazy ceiling of sky. It's positively nuclear tonight. I wish I had some steps to take me there. When Jimi Hendrix kissed the sky, he excused himself. I would not.

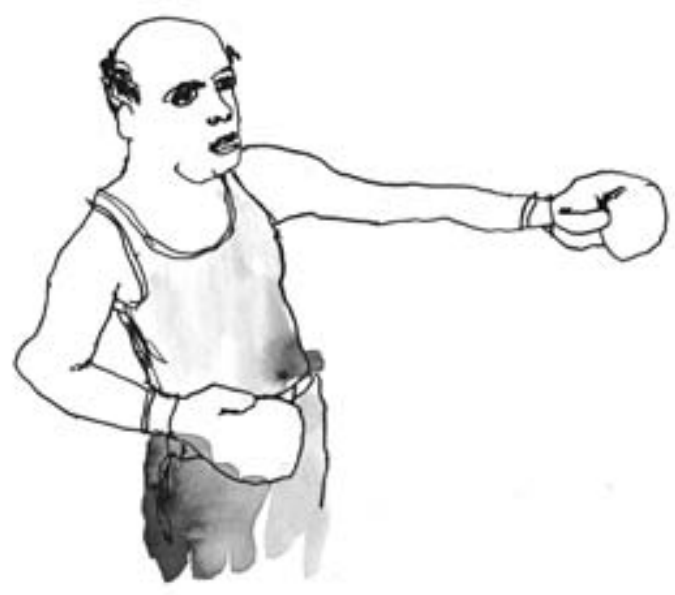

Figure 17 Hitting the Ceiling: An American Homeowner warms up before hitting the Ceiling.

\section{LAWN SCHOOL}

I.) Acquire seeds.

2.) Go out into the yard and make like Screamin' Jay Hawkins. 


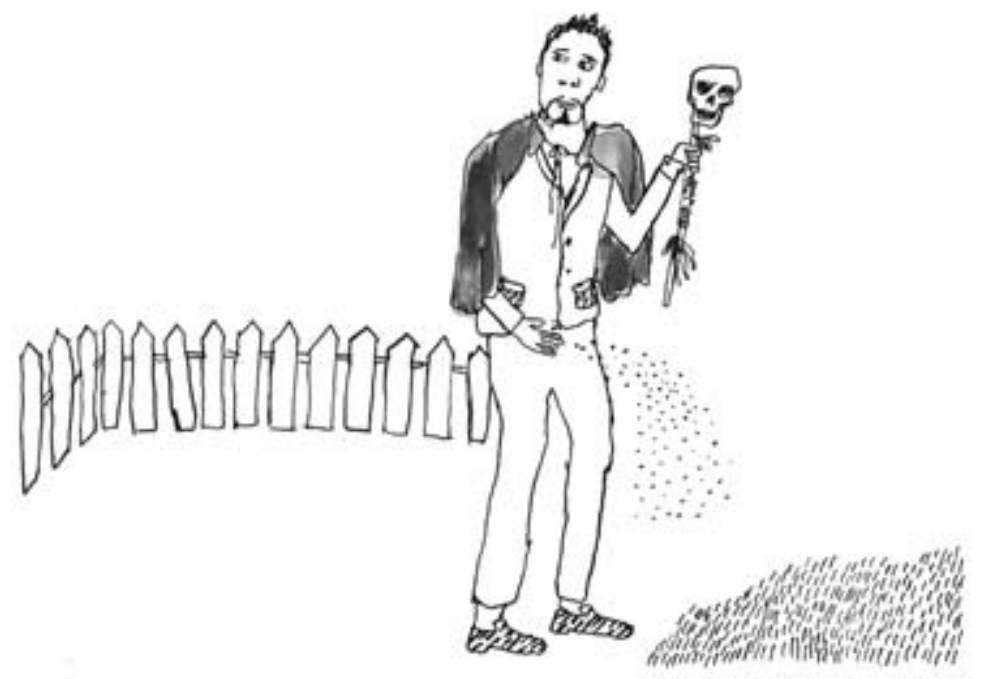

Figure 18 Yard Seeding: Screamin' Jay puts a spell on his lawn.

DOMESTIC FESTIVITIES

\author{
A Party \\ A Part A \\ $A$ Part $B$ \\ A Part E \\ Birthday Party \\ Belated Birthday Party \\ Bachelor Party \\ Bachelorette Party \\ Cocktail Party \\ Costume Party \\ Dance Party
}


62 Ryan Ridge

\author{
Dinner Party \\ Donner Party \\ Graduation Party \\ Housewarming Party \\ Farewell Party \\ Welcome Home from War Party \\ Surprise Party \\ Orgy \\ Shower \\ Wake
}


American Homes is where the party's at. American Homes is where hope goes to dream big dreams. American Homes is waking up. American Homes is afraid of foreclosing. American Homes is location, location, location. American Homes is writing books despite the supposed death of the author. American Homes is setting the doghouse on fire on the lawn. American Homes is getting high on the roof of a hospital. American Homes is lowdown delta blues. American Homes is dressed up as the Statue of Liberty, twirling a sign for a furniture store on the side of the road. American Homes is networking with homeowners. American Homes is drifting on a raft reading an unedited version of Huckleberry Finn. American Homes is American Literature. American Homes is the sequel to the igth Century. American Homes is sleeping on a houseboat. American Homes is travelling on a Greyhound bus in search of a perfect neighborhood. American Homes is putting a flower in the mouth of a police rifle at a housing riot in the future. American Homes is currently living in a tent behind William Vollmann's American Home. American Homes is haunted by the voices of American Homes. 
Different Voices /

Different Rooms 


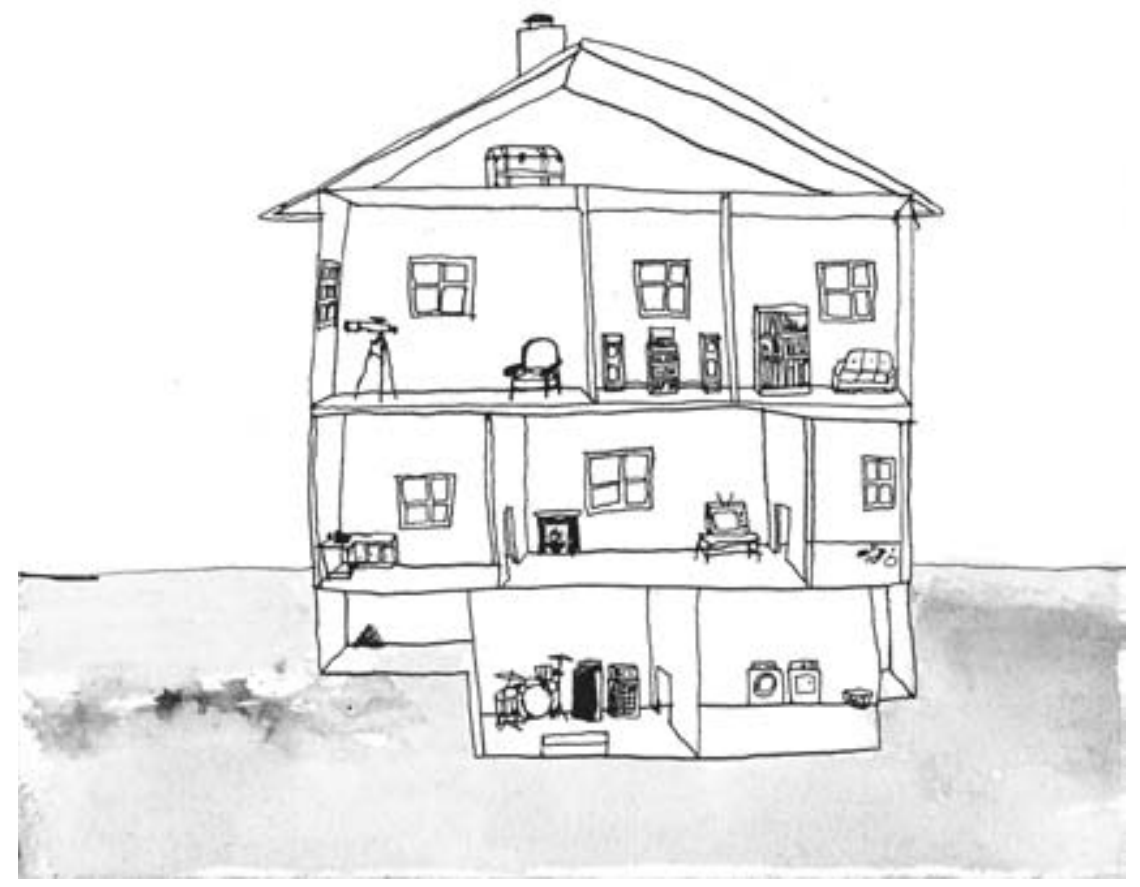

\section{AMERICAN ATTICS}

There's a light on in the attic.

But it's an anomaly.

These days most attics suffer from neglect.

I have come to this attic to no longer neglect it. I have come to this attic to store my recent nostalgia. I have come to this attic to hide from the spy satellites. 
Wallace Stevens, after the birth of his first child, moved his writing room to the attic of his American Home so it would be possible for him to smoke and loaf and read and write sometimes. Often he just slept.

I have come here to smoke and loaf and write.

As days slip past listlessly in my back catalogue.

I have been sleeping lately, but not too well.

Why are so many nightmares set in attics?

I imagine it has something to do with the failed imaginations of Hollywood.

Yet I feel complicit.

Politics.

William Henry Harrison, the ninth American president, died of the pneumonia he caught on Inauguration Day (within a month of taking office).

Harrison, dead, now haunting the White House attic.

American Dream Attic Guard.

I cast a nostalgic glance back. Old photographs.

But the future is a multiple orgasm.

It just keeps coming.

(Apologies for the joke.) 


\section{Most attics are dry. \\ That's no joke.}

W.C. Fields, fearing the return of Prohibition, hid hundreds of cases of whiskey in the attic of his American Home.

Attics are ideal places to hide most anything.

Guests just don't go there.

In part it's what we hide that makes us who we are.

Clothes are proof.

I will now open the attic window.

Henry James recommended always keeping an attic window open; not just cracked: open.

Open windows are invitations to the wind.

But what does "open" even mean in a $24 / 365$ World?

I am not averse to "progress."

I, for one, am open to the idea of robots owning American Homes.

Most of the founding fathers were averse to attics.

My own father kept his Vietnam War medals in the attic until one Christmas my mother framed them and gave the frame to him as a gift. Now the framed medals are in the same attic, collecting dust.

Our Narrator thinks this chapter would possibly be more exciting if it were about American Addicts instead of American Attics. 
Insert Garland. Insert Burroughs. Insert needle.

One American Homeowner smokes Angel Dust in his attic abode and sees a door where there is actually a window.

Collecting dust is an attic's occupation.

I am occupied with attics.

Another Homeowner sees something in the periphery of his attic and thinks it's a ghost.

A rodent perhaps?

Raccoons, rats, squirrels, termites: all bound by their attraction to attics.

$\mathrm{Me}$, too, it seems.

Why are so many ghost stories set in American attics?

Our Narrator suspects it has a great deal to do with American history.

Our Narrator also suspects it has something to do with the occult.

Attics. Addicts. Attics.

Where we relegate the contents of our days we are as of yet unable to discard.

We are astronauts of storage space.

Fast, too, becoming pirates of cyber space.

I have nothing to hide. 
In an age of total transparency it's becoming increasingly difficult to hide anything.

In an age of total transparency attics are becoming obsolete.

So we go on neglecting them and continue putting the contents of our attics on the internet for sale.

Like those unused baby shoes I purchased from the Ernest Hemingway estate.

Or those old soul records I bought for nothing on eBay. Of which I have come here to listen.

Tonight, I will smoke and loaf and listen and maybe write. And it will be a long time before I turn out the light. 


\section{AMERICAN BASEMENTS}

As a young man, wasting my high school years getting high in my parents' basement in Non-fictionville.

Remembering now not remembering much else about that basement except its smell.

Also taking LSD in the same basement numerous times. Losing mind temporarily.

Losing virginity forever there, too.

Some men can live up to their loftiest ideals without ever going higher than a basement.

Unquote. Theodore Roosevelt.

Abraham Lincoln's youngest son, Tad, lost in the bowels of the U.S. Capital building's basement.

The same basement allegedly haunted by a demon cat. Color: black.

Edgar Allan Poe, who wrote "The Black Cat" in an American Basement in Baltimore.

The basement of an American Home in Hartford, Connecticut, Noah Webster haunts.

Perennially overrun with rats, mildew, and foul smells.

Said Secretary of State William Stoddard, of the White House basement circa 1863. 
Stoddard, who often accompanied Mrs. Lincoln to the basement to retrieve fine wines.

The White House basement turned bowling alley circa Truman.

Curious as to the origins of the thousands of human bones buried in the basement of Benjamin Franklin's British Home.

Also wondering when and if they'll excavate the basement of his American Home.

An impromptu nightclub in John Wayne Gacy's American basement where he seduced underaged boys with alcohol and money. Telling them it was all in the name of science.

Thomas Edison, age ten, building a science lab in his parents' basement where he spent days on end experimenting. Edison's father, Samuel, attempting to bribe his son out of the room with pennies. Failing.

Neil Armstrong, age fourteen, building a wind tunnel in his parents' basement and testing its effects on model airplanes.

B.F. Skinner's basement, where, as an adult, he discovers his inner child.

Remembering a story about Jackson Pollock's best painting locked away in an Iranian basement. 
Alfred Hitchcock. Terrified of everything, especially basements.

Pee-wee Herman's quixotic quest for the basement of the Alamo.

Davy Crockett, who did not die there.

Samuel Clemens, who thought up the name Mark Twain in an American basement.

Basements, which gave Kurt Vonnegut visions of Dresden and fire.

Kurt Cobain liked to nod off in basements.

Elliott Smith's posthumous album: From a Basement on a Hill.

Q: Where can you go when your money gets low?

A: In the basement.

This, according to the gospel of Etta James.

The Louis Armstrong Museum in Queens, housed in the basement of Armstrong's former American Home.

Sinatra's basement, where he kept his toy trains.

The lost Woody Guthrie records discovered in an American basement in Brooklyn.

Bob Dylan's Basement Tapes. 
Johnny's in the basement. Mixing up the medicine. I'm on the pavement. Thinking about the government.

Muhammad Speaks, the newspaper Malcolm X printed in the basement of his American Home.

As a method of treating mental illness, Patrick Henry kept his wife, Sarah Shelton, locked in the basement of their American Home. Sarah Shelton, who originally coined the phrase Give Me Liberty or Give Me Death.

Don't you ever just want to lock some things in a basement and just throw away the key?

No basements.

Said Frank Lloyd Wright who hated basements and rarely included them in his American Home designs.

James Fenimore Cooper, visiting Italy, laments the lack of basements.

I, The Narrator, living in an apartment with no basement.

I, The Narrator, revisiting my parents' basement in Nonfictionville.

I, The Narrator, who feels sentimental every time I hear the word "basement."

Basement. 
74 Ryan Ridge

\section{THE GHOST OF MARK TWAIN MEDITATES ON} AMERICAN BATHROOMS

it from an American humorist, most American humor originates in American Bathrooms and most of it smells accordingly. 


\section{AMERICAN BEDROOMS}

The gods said never start a piece of writing with a character waking up in bed.

But here I am, half-asleep, narrating from my mattress in Non-Fiction City.

A bedroom requires a bed, she said.

She, being actress Audrey Meadows, whose American Home featured six bedrooms, nine baths, and an elevator.

They say her American Home was positively European.

In the bedroom at Monticello, at the foot of Thomas Jefferson's bed, a machine he'd invented with forty-eight projecting hands on which he hung his suits and wigs.

For fourteen years, I lit a fire there.

Said Sally Hemings re: Jefferson's bedroom fireplace.

In an American Home in Amherst, MA: Emily Dickinson's bedroom window, overlooking the town graveyard.

The ghost of Betsy Ross crying at the foot of her bed in her former American bedroom in Philadelphia.

Lincoln's ghost, at the window of the White House guest bedroom, gazing sagely at the Potomac.

Lincoln's bedroom! And you see that great bed, it looks like a cathedral. 
Said Jacqueline Onassis, her first night in the White House. Jacqueline Onassis, who died thirty-three years later, in the bedroom of a New York City apartment.

A bedroom is the perfect place to fall apart.

Said Margot Kidder, and she wasn't kidding.

Overheard: slow eaters are fast in the bedroom.

I'm so fast that last night I turned the light switch off in my bedroom and I was in bed before the room was dark.

Said Muhammad Ali, who owns three American Homes—all with multiple bedrooms.

Franklin D. Roosevelt: famous bed-wetter.

J. Edgar Hoover knew what was happening in many American Bedrooms.

JFK. MLK. RFK.

The likelihood that Michael Jackson slept in a hyperbaric chamber.

The likelihood he also slept with children.

No one has stepped foot in Elvis's bedroom at Graceland since I977, the year he died.

Books in the bedroom: bad Feng Shui.

Televisions in bedrooms: worse. 
Bedrooms in basements: bad idea.

Fireplaces in the bedroom: hot.

Above Jefferson's bed, a skylight.

Beneath James Madison's: a junk food wrapper.

In Herman Melville's: his wife and children sleeping.

Moby Dick begins in a bedroom.

So much ends continually, especially in the wild bedrooms of the sea.

Fact: Bedrooms are where virginity goes when it's lost. (Source: NACSA)

Lyrics on a teenager's bedroom wall in the '9os:

The sun shines in the bedroom

When you play

And the raining always starts

When you go away

-The Vaselines

Rooms require room.

Bedrooms require beds.

What do you call a bedroom without a bed?

The gods also said to never end a story with a character waking up in bed, even if he's holding a weapon and wondering.

What about epiphanies in bedrooms?

Okay. Sure. 
My epiphany: I may have just had an epiphany.

Here on my bed in my apartment in Non-Fiction City.

In the Land of American Homes.

A maybe epiphany.

It was about death.

Aren't they all?

Jefferson died in his bedroom, broke, his creditors removing the remaining family within days.

What is the likelihood of dying in your own bed?

What is the likelihood of dying in someone else's?

American Hospitals. American Homes. American Graveyards. 


\section{BEYOND BED BATH \& BEYOND}

I believe it was astronaut John Glenn who said: "Let us go beyond Bed Bath \& Beyond.” Yes, let's. 


\section{AMERICAN KITCHENS}

They say the kitchen is the heart of the American Home.

I heart kitchens.

I never learned to cook because I am too thin.

I am too thin because I never learned to cook.

Fire is the original kitchen.

No bitchin' in this kitchen. No food either.

I would like to turn my kitchen into a vending machine.

If you can't stand the heat, get out of the kitchen. Said Harry S. Truman who also never learned to cook.

Bill Clinton liked to cook when he was young. Before he discovered McDonald's hamburgers.

George W. Bush's insistence that a salad bar-complete with sneeze guard-be added to the White House kitchen.

Washington's monumental appetite. At least three hot meals served daily in the Mount Vernon kitchen courtesy of wife Martha and diligent slave Leroy. 
Thomas Jefferson's muffin recipe:

$$
\begin{aligned}
& 4 \text { cups of flour } \\
& \text { I- I/2 packets of yeast } \\
& \text { I-I/2 cups water } \\
& \text { cast iron griddle }
\end{aligned}
$$

The Amelia Earhart Museum gift shop in Atchison, Kansas-housed in Earhart's childhood kitchen.

Show me a man who lives alone and has a perpetually clean kitchen, and eight times out of nine I'll show you a man with detestable spiritual qualities.

Said Bukowski, who sometimes drunkenly urinated in the kitchen sink.

Comedian Rodney Dangerfield, tired of sex and turned on by food, joked about putting a mirror on the ceiling above his kitchen table.

A kitchen knife cannot cut itself.

American proverb.

Abraham Lincoln's Scalloped Oyster Recipe:

$$
\begin{gathered}
\text { I/ } 4 \text { cup butter, melted } \\
2 \text { cups coarse cracker crumbs }
\end{gathered}
$$

2 dozen oysters, scrubbed, shucked, drained, with liquid reserved

$\mathrm{I} / 4$ teaspoon pepper

$\mathrm{I} / 3 \mathrm{cup}$ cream 


$$
\begin{gathered}
2 \text { tablespoons sherry } \\
\text { I teaspoon Worcestershire sauce }
\end{gathered}
$$

Martin Luther King Jr.'s favorite food: pecan pie.

American Kitchens as Meth Labs.

American Kitchens as Assembly Lines.

American Kitchens as Museums for Pre-Adolescent Art.

Richard Nixon's Kitchen Debate.

William Vollmann's kitchen is a bedroom.

Kitchen Gods: appliances.

Kitchenettes: dwarves.
A fat kitchen, a lean will.
Unquote. Benjamin Franklin.

Jackson's Kitchen Cabinet: Martin Van Buren, Francis Preston Blair, Amos Kendall, William B. Lewis, Andrew Jackson Donelson, John Overton, and Roger B. Taney.

Ernest Hemingway's Bloody Mary recipe:

$$
\begin{aligned}
& \text { I chunk of ice (the biggest that will fit) } \\
& \text { I pint of vodka } \\
& \text { I pint chilled tomato juice } \\
& \text { I tablespoon "Worcester" sauce }
\end{aligned}
$$




\author{
I jigger fresh lime juice \\ Pinch celery salt \\ Pinch cayenne pepper \\ Pinch black pepper \\ Several drops of Tabasco
}

Ever been to Hell's Kitchen?

No, what do they serve?

Contrary to popular belief, thirteen husbands have been shot dead while doing the dishes.

Contrary to popular belief, Velveeta did not invent mac and cheese.

Thomas Jefferson did.

He was a damn fine cook.

Never fuck with the cook or the cook will fuck with you. Kiss the cook. 
Living Rooms, the greatest of all earthly blessings—give us those precious jewels and you may take everything else. A single Living Room is worth all the other rooms that have ever been built. This is all the inheritance I can give my dear family. Give me Living Rooms or give me more death! 
THE SECRET ROOM CONFESSES ITS SHAMEFUL SECRET

Mold, mold, mold, I have mold! 


\section{AMERICAN GUEST ROOMS}

What art offers is space.

Updike said.

The same can be said for moon colonization.

One time I shot for the moon but instead I ended up crashing in a guest bedroom.

Come on in, she said.

Be my guest.

Let me show you to your room.

A guest room is only as civil as its occupants.

As disobedient as its ghosts.

Abraham Lincoln's ghost sobbing in a White House guest room.

The guest room is a room reserved for cameos, never stars.

Tonight, I am making a brief appearance on this wide, thin bed.

Tonight I have a dream.

Tomorrow I will forget.

What is a guest without a host?

Don DeLillo noted the helix-like interplay between the two words.

Guests bring in ideas from outside the home, he said. 
They, like writers, are agents of change.

Parasites perhaps.

(If they stay too long.)

The trick to being a good guest is to keep it short.

Fish and visitors smell in three days.

Said Benjamin Franklin who knew a thing or two about foul smells.

(See: American Basements)

Some guest rooms are actually houses.

Guest houses?

Only in the Land of American Homes.

Anybody in L.A. knows the best places to live are guest houses.

This according to Kato Kaelin, who lived in O.J.'s guest house.

Simpson's bloody glove discovered behind said house.

Personally, I don't have a guest house or even a guest room, but if I did I would name it Christopher.

Welcome to the Christopher Guest Room.

If I had a guest room, I'd turn it into a talk show.

Tonight my guest is Kato Kaelin.

We will be discussing the shortage of second acts in American lives.

What good is sitting all alone in your guest room, Christopher?

Come out and visit. 
Stay awhile.

But not too long.

I fell from my high horse and emerged from a guest room.

Put a television in a guest room and the room will seem more entertaining.

Put a mirror in a guest room and it'll seem more spacious.

Put a guest in a guest room against their will and then you'll have a hostage situation.

A guest room without guests is a relief.

A guest room without books is regrettable.

And so, too, is an uninvited guest.

And the only thing worse than an uninvited guest is an uninvited guest room.

A guest room is not unlike a hotel within the home.

A hotel staffed solely by volunteers.

Whenever I sleep in a guest room, even a comfortable one, I wake up feeling disoriented and alarmed.

Does anyone else feel this way?

Wondering if rock stars also trash guest rooms.

(Are there even such things as rock stars anymore?)

Curious as to the contents of these guest room drawers.

Guest room closets.

Searching. Not finding anything here of interest. 
These days not finding much of interest, shiftless.

I should just sit and enjoy my status as a "guest."

But I can't sit still.

All human evil comes from a single cause: man's inability to sit still in a room.

Said Pascal.

And here I am, fidgeting in this guest room.

I'm fidgeting because I'm anxious.

I'm anxious because I woke up here: disoriented and afraid.

What am I afraid of?

Mostly death.

R.I.P.

In a White House guest room, Willie, the eleven-year-old son of Abraham and Mary Lincoln, died.

All rooms are guest rooms in the end.

All houses, guest houses.

Let us enjoy our status as guests. 
American Homes is making a pilgrimage to the graves of dead architects. American Homes is vacationing in an undeveloped country attempting to develop it like film. American Homes is returning to school to become an X-ray technician. American Homes is purgatoried on an L.A. freeway. American Homes is hoping to be interviewed by The Paris Review. American Homes is writing an indignant response to American Homes called A Rebuttal to American Homes. American Homes is made in Made in America. American Homes is drinking wine with the homeless men again. American Homes is shooting sunbeams out of its eye sockets. American Homes is living on Chinese credit. American Homes is doing cocaine in the bathroom of the House of Blues in South Carolina. American Homes is overeating at an International House of Pancakes in Southern Indiana. American Homes is getting lost in a house of mirrors. American Homes is sifting through shards of broken mirrors. American Homes is leaning out the window and posing for the spy satellites. American Homes is waving at the drones. American Homes is traveling abroad, contemplating European homes. American Homes is wandering through a cemetery, searching for a decent epitaph. American Homes is purchasing prime real estate in heaven. American Homes is training to watch a marathon on television. American Homes is running to the store for more ice. American Homes is never running out of ideas. 
Ideas 
American Homes is a book of ideas.

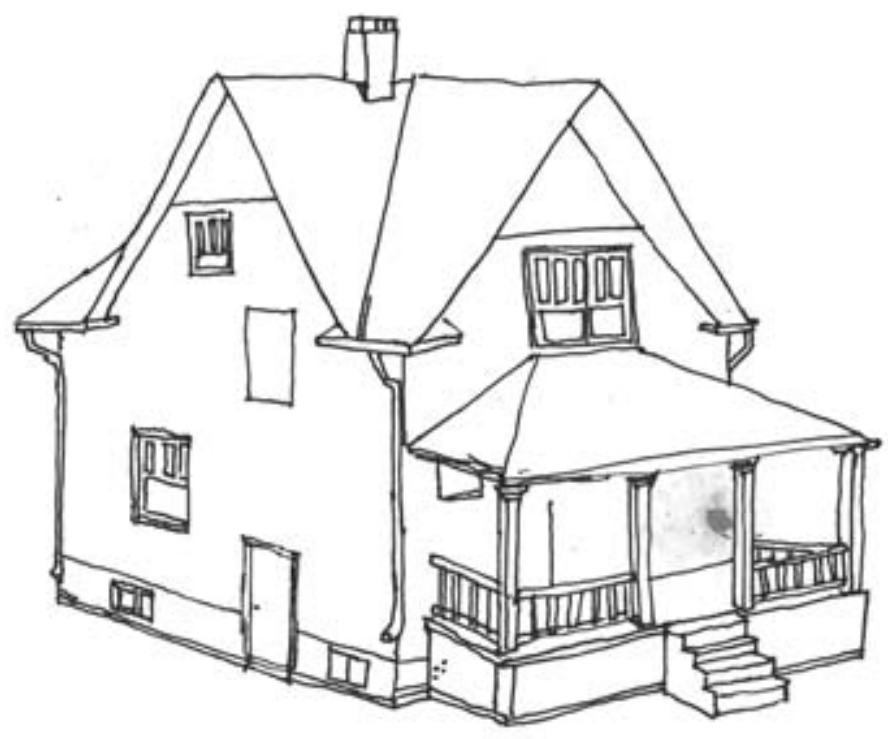


Gandhi's Idea

"What do I think of American Homes? I think it would be a very good idea." 
94 Ryan Ridge

Idea for Garage

I think a great garage would be one where you could start your car in it and your car would turn into a successful band. 


\section{Idea for Hallway}

I think an ideal hallway would be one that, rather than connecting two rooms, it connected you to important people in the White House. 
96 Ryan Ridge

\section{Idea for Closet}

A really dreamy closet would be a place where, instead of storing your clothes and shoes, you could store your dreams-an archive of the unconscious mind. Last night I dreamed I turned my closet into a natural history museum and people came from all around to gaze at the bones. 
Idea for Foyer

I have no idea of what to do with or in a foyer. Make it less awkward somehow? I don't know. 
98 Ryan Ridge

Idea for Skylight

Install Tungsten lights in your skylight and then every night is American Night. 


\section{Idea for Nursery}

Turn your nursery into a "nursery" with a hydroponic system. 
100 Ryan Ridge

\section{Idea for Outdoor Office Chair}

Porch Swing. 


\section{Idea for Porch Swing Party}

Put a couple swingers on a Porch Swing and it becomes a Porch Swinger. 
102 Ryan Ridge

\section{Idea for Kitchen Sink}

Instead of throwing everything in but the kitchen sink, I suggest building a kitchen sink large enough to throw everything in it. 


\section{Idea for Dining Room}

I'd like to turn my dining room into a waffle house: everything, even the furniture, would be made of waffles. Then, once I've finished construction on my dining room, I'd invite a bunch of drunks over for breakfast for dinner. 
104 Ryan Ridge

\section{Idea for Home Antenna*}

Build an antenna with a signal strong enough to pick up local singles without leaving your American Home.

*NOTE: This idea later became known as the internet. 
Idea for Balcony

If you'd like a notable balcony then have someone notable stand on your balcony. 
106 Ryan Ridge

\section{Idea for White House}

If we painted the White House pink and made it a bit smaller, America would be exactly like living in a John Cougar Mellencamp song. 


\section{Idea for American Dream House}

One in which you wake up happy. Every day you wake up happy. You wake up and you're happy every day. 
108 Ryan Ridge

\section{Idea for Neighbors}

No neighbors. No fences. Just meadows, endless meadows, meadowing endlessly. 


\section{Idea for Stairs}

Stairs that keep going up, up, up, up past the summit of the home, into the sky, into the space beyond sky, beyond space, into light, beyond light, into forever and then back down the stairs, all the way back, back to the land of American Homes, back to the source, back to the home. Welcome home. 


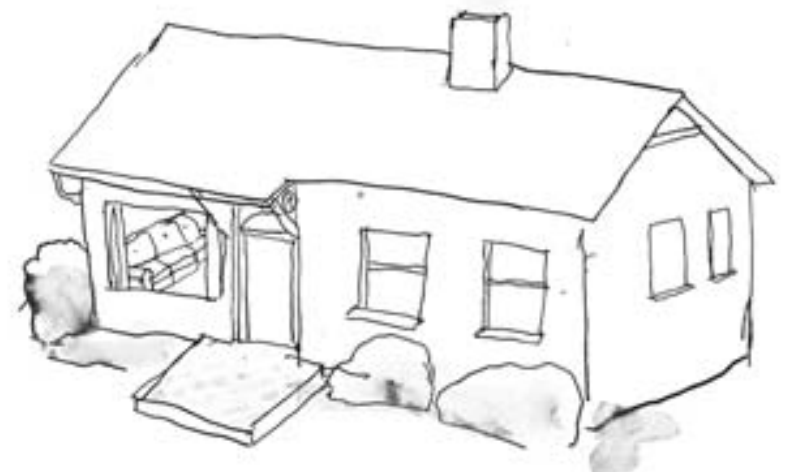

Per aspera ad astra. 


\section{Index}

Air Guitar, 42, 44, 48

Air Guitar Cases, 45

Ali, Muhammad, 76

Alice in Chains (band), 54

Amherst, Massachusetts, 75

Annual Knuckle Precipitation, II

Arizona (state), 56

Armstrong, Louis, 72

Armstrong, Neil, $7 \mathrm{I}$

Atchison, Kansas, 8I

attics, 65-69

attic door, 15

awning, $3 \mathrm{I}$

awning window, 23, 27

back door, II

back porch, 7

bachelor party, 6r

bachelorette party, $6 \mathrm{I}$

balcony, I05

banisters, 44-45

basements, 25, 70-73, 77

basement door, 15

bathrooms, 74, 90

bathroom door, 16

bay window, 24

bedrooms, 75-78, 82, 86

bedroom door, 16

Behind the Green Door (film), I9

belated birthday party, $6 \mathrm{I}$

birthday party, 6 I
Blair, Francis Preston, 82

blinds, 32

bow window, 25

Bukowski, Charles, 8I

Burroughs, William S., 68

Bush, George W., 8०

cabinets,16, 82,

carports, 53

casement window, 25

ceilings, 59-60, 8I

cellar door, I4-I5

chimney, 36-38

The Church of Jesus Christ of Latter-day

Saints, II, I7

Clancy, Tom, 8

Clemens, Samuel, 72

Clemons, Clarence Jr., 7-8, 42, 48, 49, 53

Clinton, Bill, 80

closet, 88,96

closet door, I6-I7

Cloud Quakes, 25, 37

Cobain, Kurt, 72

Cooper, James Fenimore, 73

"Crazy Train" (song), 48

curtains, 33

Dangerfield, Rodney, 8I

Davis, Gary, 32

Debs, Eugene, 34

decks, 7

DeLillo, Don, 86 
delta blues, 63

Dickinson, Emily, 75

dining room, $\mathrm{IO}_{3}$

Donelson, Andrew Jackson, 82

doorbell, 20

The Door in the Floor (film), 19

doors, 9-20, 27, 68,

The Doors (film), 19

dormer window, 25-26

double hung window, 26

dream house, 107

driveways, 50, 55-57

Dylan, Bob, 28, 72

Earhart, Amelia, 8I

Edison, Thomas, 7I

egress window, 26

fallout shelter door, I7

Fatboy Slim (DJ), 54

Fields, W.C., 79

fireplace, 37, 39-40, 75, 77

fixed window, 26

Floorganic Chemistry, 59

floors, 43, 58-59

Florida (state), 3

flue, 38

Fogle, Jared, 53-54

foyer, 97

Forbes Magazine (magazine), 37

frames, 33

Franklin, Benjamin, 71, 82, 87

Freedom Window, 27

Freemasonry, 42

French door, 13

French window, 27

front door, IO-II, 2O, $3 \mathrm{I}$

front porch, 4-5, 7, 10, 42

furnace, 39

Gacy, John Wayne, 7I

Gandhi, 93

garage, 50-54, 94

garage door, 12

garage sails, $5 \mathrm{I}-52$

garage sales, $5 \mathrm{I}$
Garland, Judy, 68

Glenn, John, 79

God, 42, 44

The Golden Door (film), I9

Graceland, 76

Guest, Christopher, 87

Guthrie, Woody, 72

gutters, 38-39

hallway, 95

Harrison, William Henry, 66

Hawkins, Screamin' Jay, 6r

Hemings, Sally, 75

Hemingway, Ernest, 69, 82

Hendrix, Jimi, 60

Henry, Patrick, 73, 84

Hilson, Keri, 32

Hitchcock, Alfred, 72

Hoover, J. Edgar, 76

hopper window, 27

Huckleberry Finn (novel), 63

ideas, 9I-Io9

Indiana (state), 90

International House of Pancakes (restau-

$$
\text { rant), } 90
$$

The Internet, 42, 69, I04

Iran (country), 3, 7I

Jackson, Andrew, 82

Jackson, Michael, 76

Jacuzzi, 28

jalousie window, 27-28

James, Etta, 72

James, Henry, 67

Jefferson, Thomas, 75, 77, 78, 8I, 83

Kaelin, Kato, 87

Kendall, Amos, 82

Kennedy, John F., 76

Kennedy, Robert, 76

Kidder, Margot, 76

King, Martin Luther, Jr., 76, 82

kitchens, 80-83

kitchen sink, IO2

landings, 44, 46-47

lawns, 6o-6r 
Lincoln, Abraham, 70, 75, 8I, 86, 89

Lincoln, Mary, 7I, 89

Lincoln, Tad, 70

Lincoln, Willie, 89

living rooms, 84

LSD, 70

Lysol, Antonio, I6

Madison, James, 77

Mad Max (fictional character), I7

Magritte, René, 4I

McDonald's (restaurant), 80

McGaffey, Ives W., 59

McTell, Willie, 32

Meadows, Audrey, 75

Mellencamp, John Cougar, 106

Melville, Herman, 77

Mike \& the Mechanics (band), 54

Moby Dick (novel), 77

Muhammad Speaks (newspaper), 73

NASCAR, 56

"The Needle and the Damage Done" (song), I4

neighbors, Io8

New York, New York, 76

Nixon, Richard, 82

nursery, 99

$\mathrm{Nu}$ American Center for Statistical

Analysis (NACSA), 4, 13, 15, 23, 25, 27, $3 \mathrm{I}, 33,43,5 \mathrm{O}, 58,77$

Oklahoma (state), ${ }_{5} 6$

Onassis, Jacqueline, 76

Overton, John, 82

Page, Jimmy, 44

The Paris Review (magazine), 90

Pascal, Blaise, 89

patio door, I2-I3

patios, 7

Pee-wee Herman (fictional character), 72 pet door, 26

Philadelphia, Pennsylvania, 75

picture window, 28

Poe, Edgar Allan, 70

Potomac (river), 75
Pollock, Jackson, 7I

porch swing, 5-7, 100

prison, 2I, 33

prison wind, 25, 33-34, 37

purple rain, 25, 39

Reagan, Ronald, 38

replacement window, 28

Ridge, Ryan, 3-IIO

roof, $36-37$

Roosevelt, Franklin D., 76

Roosevelt, Theodore, 70

Ross, Betsy, 75

Santa Claus, 37

screen door, 14

screens, 33

secret rooms, I7, 97

The Seventh Door (film), I9

Shag, Archibald, 59

sheds, 53

Shelton, Sarah, 73

side door, 12

Simpson, O.J., 87

Sinatra, Frank, 72

single hung window, 28-29

Skinner, B.F., 7I

skylight, 29-30, 77, 98

Sliding Doors (film), I9

Smith, Elliott, 72

Stairmastery, 42-46

stairs,?43-49, I09

Stairway to Heaven (song), 44

stairway, 43

Stevens, Wallace, 66

Stoddard, William, 70

storm door, 13

Taney, Roger B., 82

tinted windows, 34

transom window, $3 \mathrm{I}$

Transom, Theodore, 23, 28, 46

trapdoor, $17-18$

Truman, Harry S, 7I, 80

Tucson, Arizona, 3

Twain, Mark, 72, 74 
United States Constitution, 42, 55

Updike, John, 86

Utah (state), I7

Van Buren, Martin, 82

Various Interior Doors (VIDs), 15-18

Velveeta (cheese), 83

vindauga, 2I

Vollmann, William, 63, 82

Vonnegut, Kurt, 72

walls, 58

Walton, Frederick, 59

Washington, George, 92
Washington, Leroy, 92

Washington, Martha, 92

whiskey, 6o, 67

The White House, 66, 70-71, 75-76, 80, 86,

89,95, Io6

window sills, 33

Windowers, 2I

Wright, Frank Lloyd, 53, 73

$\mathrm{X}$, Malcolm, 73

Young, Neil, I4

Zen koan 


\section{Home Builders’ Association}

Ryan Ridge is the author of the story collection Hunters $\mathscr{E}$ Gamblers, the poetry collection $\mathrm{Ox}$, as well as the chapbooks Hey, it's America and z2nd Century Man. His work has appeared in Tin House, McSweeney's Small Chair, Salt Hill, The Santa Monica Review, The Los Angeles Review, Hobart, and elsewhere. Managing Editor at Juked, he lives in Louisville, Kentucky.

Jacob Heustis is a native of Louisville, Kentucky, where he lives and works. In 2004, he had his first solo exhibition at Swanson Reed Contemporary and has shown in numerous group exhibitions and solo shows since. He has also designed album covers for the indie bands Wax Fang, Silver Tongues, and Whistle Peak, among others. His work is held by several public and private collections. 


\section{Ist Century Prose}

Series editor: Matthew Vollmer, Virginia Tech

The 2ist Century Prose series celebrates varieties of forms-of prose that breaks the rules, bends conventions, and reconfigures genre. The books in this series engage playfulness and experimentation without sacrificing accessibility and readability. The voices represented in the series come alive on the page through prose that is at once down-to-earth and also a reflection of an artist at home with his or her improvisations. Lifeaffirming but convention-defying, the language in these books strives to be both groundbreaking and readable. The 2Ist Century Prose series listens for and endorses voices that have been marginalized, reports from zones-physical and spiritual and emotional—from which we have yet to hear. Kind-hearted renegades. Things we can't describe but that leave us pleasantly puzzled, forcing us to say, "listen, just read it."

Books in the Series:

Full Metal Jhacket

Matthew Derby

A Heart Beating Hard

Lauren Foss Goodman

Settlers of Unassigned Lands

Charles McLeod

American Homes

Ryan Ridge 